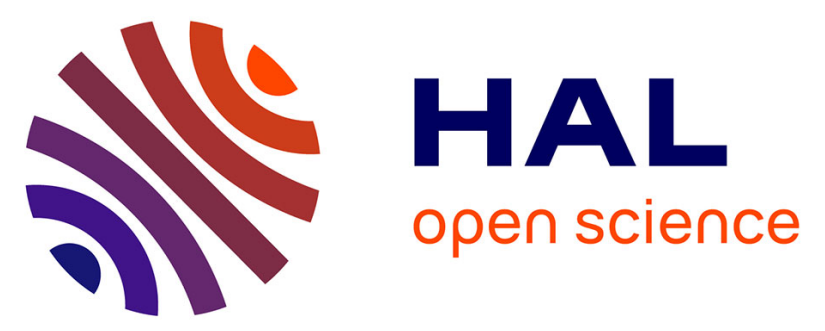

\title{
Batch biohydrogen production from dilute acid hydrolyzates of fruits-and-vegetables wastes and corn stover as co-substrates
}

Santiago Rodríguez-Valderrama, Carlos Escamilla-Alvarado, Jean-Pierre

Magnin, Pasiano Rivas-García, Idania Valdez-Vazquez, Elvira Ríos-Leal

\section{To cite this version:}

Santiago Rodríguez-Valderrama, Carlos Escamilla-Alvarado, Jean-Pierre Magnin, Pasiano RivasGarcía, Idania Valdez-Vazquez, et al.. Batch biohydrogen production from dilute acid hydrolyzates of fruits-and-vegetables wastes and corn stover as co-substrates. Biomass and Bioenergy, 2020, 140, pp.105666. 10.1016/j.biombioe.2020.105666 . hal-02951141

\section{HAL Id: hal-02951141 \\ https: / hal.univ-grenoble-alpes.fr/hal-02951141}

Submitted on 30 Nov 2020

HAL is a multi-disciplinary open access archive for the deposit and dissemination of scientific research documents, whether they are published or not. The documents may come from teaching and research institutions in France or abroad, or from public or private research centers.
L'archive ouverte pluridisciplinaire HAL, est destinée au dépôt et à la diffusion de documents scientifiques de niveau recherche, publiés ou non, émanant des établissements d'enseignement et de recherche français ou étrangers, des laboratoires publics ou privés. 


\section{Batch biohydrogen production from dilute acid hydrolyzates of fruits- and-vegetables wastes and corn stover as co-substrates}

4 Santiago Rodríguez-Valderrama ${ }^{1,2}$, Carlos Escamilla-Alvarado ${ }^{1, *}$, Jean-Pierre Magnin ${ }^{2}$, Pasiano Rivas-García1, Idania Valdez-Vázquez³ ${ }^{3}$ Elvira Ríos-Leal ${ }^{4}$

1/Universidad Autónoma de Nuevo León, Centre for Research on Biotechnology and Nanotechnology

8 (CIByN), Faculty of Chemical Sciences, Engineering and Sustainable Bioprocesses Group, Parque de Investigación e Innovación Tecnológica, km 10 Highway to International Airport Mariano Escobedo,

10 66629, Apodaca, Nuevo León, México

2Univ. Grenoble Alpes, Univ. Savoie Mont Blanc, CNRS, Grenoble INP, LEPMI, 38000 Grenoble, France.

12 3Universidad Nacional Autónoma de México, Laboratory for Research on Advanced Processes for Water Treatment, Instituto de Ingeniería, Unidad Académica Juriquilla, México.

$14{ }^{4}$ CINVESTAV-I.P.N., Environmental Biotechnology and Renewable Energies R\&D Group, Department of Biotechnology and Bioengineering, Mexico City, México

${ }^{*}$ Author for all correspondence:

20 Carlos Escamilla Alvarado, ScDr.

Engineering and Sustainable Bioprocesses Group

22 Centre for Research on Biotechnology and Nanotechnology (CIByN),

Faculty of Chemical Sciences

24 Universidad Autónoma de Nuevo León

Apodaca, Nuevo León, Mexico

26 Tel.: +52 8183294000

E-mail: cea_escamilla@yahoo.com.mx

28

30 


\section{Batch biohydrogen production from dilute acid hydrolyzates of fruits- and-vegetables wastes and corn stover as co-substrates}

\section{ABSTRACT}

Fruits-and-vegetables wastes (FVW) and corn stover (CS) are two of the most recurred

36 lignocellulosic biomasses used for biofuel production. In this work, the co-processing of FVW and CS for biohydrogen production was proposed and evaluated through a set of experimental designs.

38 First, a $5 \times 2$ general factorial was applied on the dilute acid pretreatment at five levels of FVW:CS ratios $(0: 1,1: 3,1: 1,3: 1$ and 1:0 dry mass basis) and two levels of the type of catalyst $(\mathrm{HCl}$ or

$40 \mathrm{H}_{2} \mathrm{SO}_{4}$ at $0.5 \%$ in volumetric basis). Then, biohydrogen production using the dilute acid hydrolyzates was carried out in batch mode at $35^{\circ} \mathrm{C}$ in a $3^{2}$ factorial design, the factors being the

42 inoculum to substrate ratio $\left(0.8,1.0\right.$, and $\left.1.2 \mathrm{~g} \mathrm{~g}^{-1}\right)$ and the initial concentration of reducing sugars $\left(10,13\right.$ and $\left.16 \mathrm{~g} \mathrm{~L}^{-1}\right)$. The effects of the type of acid catalyst and the FVW:CS ratio were significant

44 in terms of sugars production and yield. The best catalyst was $\mathrm{HCl}$ for the 3:1 $\mathrm{FVW}: \mathrm{CS}$ ratio, which produced monomeric sugars concentrations of $10.0,3.7$ and $2.9 \mathrm{~g} \mathrm{~L}^{-1}$ for glucose, xylose and

46 arabinose, respectively. The acid hydrolyzates proved to be suitable for biohydrogen production, reaching yields of $2.31 \mathrm{~mol} \mathrm{H}_{2}$ mol-1glucose and hydrogen production rates of $8.83 \mathrm{~mL} \mathrm{H} \mathrm{H}_{2} \mathrm{~h}-1$. An

48 economic prospection at lab scale demonstrated that production of hydrogen presented net revenues of 0.009 USD per $\mathrm{kg}$ of co-substrates (wet basis), resulting in $24 \%$ profitability of

50 hydrogen production over its production costs. Therefore, this co-processing is an interesting proposal with further applications on biorefinery models.

52 Keywords: dark fermentation, dilute acid, factorial experimental design, hydrolyzates, overliming. 


\section{1. Introduction}

Dark fermentation biohydrogen production has become a promising technology as it may be used

58 to process various types of organic wastes (solid or liquid). It does not require luminous energy, it has high hydrogen production rates in comparison to other biological methods and it may be

60 carried out at non-sterile conditions [1]. Lignocellulosic wastes have been highly esteemed for their abundance and bioprocessing potential [2]. Corn stover (CS) is a worldwide important

62 lignocellulosic waste; high amounts are produced in countries such as Mexico where corn production reaches 21.1 million tons yearly along with the production of up to 38 million tons of

64 corn cobs and CS [3,4].

Due to the highly stable and organized microstructure of its lignocellulosic components,

66 pretreatments are required to reduce its recalcitrance and the cellulose crystallinity to facilitate the carbohydrates depolymerization [5]. Cellulose and hemicellulose can be broken-down to its mono-

68 and disaccharides constituents by dilute acid hydrolysis. Yet the resultant sugar concentration depends on the operational conditions (i.e. reaction time, temperature, acid concentration) and

70 type of feedstock $[1,6]$. Moreover, acid hydrolyzates influence dark fermentation by many factors, such as the type and concentration of inoculum, sugars and inhibitors concentration, temperature,

72 and $\mathrm{pH}$ [7]. An excessive loading of carbohydrates may hinder the biohydrogen due to the excessive production of organic acids that lower the fermentation $\mathrm{pH}$ and promote solventogenic

74 lactic-acid oriented metabolism [2]. Therefore, the determination of an adequate inoculum to substrate ratio (ISR), which relates the amounts of inoculum fed to the bioreactor in comparison

76 to the substrate loadings, is important to foster biohydrogen production. Moreover, ISR may help reduce the inhibitory characteristic of acid hydrolysis. On the other hand, at higher proportion of

78 substrate (e.g. 1:6 ISR), hydrogen production has been inhibited due to increase of osmotic pressure that affects microbial growth [7], and the excessive production and accumulation of 80 volatile fatty acids (VFA) that cause $\mathrm{pH}$ decrease. 
CS dilute acid hydrolyzates are mainly composed of xylose since its hemicellulose content

82 present easier hydrolysis [8]. Indeed, this represents a challenge for the microbial metabolism preference of hexoses over pentoses. An opportunity to increase the hexoses content would be

84 to combine the acid hydrolysis pretreatment with that of a substrate with easier degradability, such as the fruits-and-vegetables wastes (FVW) another carbohydrates rich lignocellulosic material [9].

86

Indeed, combination of substrates has been previously assayed through the co-digestion processes. These are characterized by the simultaneous processing of an incompletely degraded

88 and microbiologically rich substrate (e.g. sewage sludge, pig manure, cow manure, waste activated sludge) and a carbohydrate rich substrate (e.g. sugarcane bagasse, rice straw, corn

90 stover, corn stalk, wheat straw, cassava stillage) [10]. Co-digestion has been resorted for its advantages, such as dilution of toxic compounds, improvement of nutrients balance

92 (carbohydrates/proteins) [11] and microbial synergies [10]. Recently, co-digestion of vegetable and food wastes with cow manure has been associated to process stability, but not necessarily

94 with improved biomethane production [12].

Even though lignocellulosic biomasses have been successfully co-digested with microbial rich

96 sludges or manures for hydrogen production (e.g. cassava stillage and food waste) [10,13], the co-processing of the CS and FVW has not been previously assayed elsewhere. Researching this

98 kind of alternatives would be useful in the development of future biorefineries by avoiding monosubstrates implicit hurdles, such as seasonality and lack of nutrients, and improving supply chain

100 management through the reduction of delivery costs and harmful impacts related to climate change and fossil depletion $[14,15]$.

102 In this work, the main aim was to evaluate how the mix ratio of FVW and CS affected the production of hydrolyzates used in biohydrogen production. Specifically, design of experiments

104 were developed for insightful determination of the effects of acid catalyst on reducing sugars production, and thereafter the effects of reducing sugars concentration and the inoculum to 106 substrate ratio on biohydrogen production. As it is becoming of utter importance to assess the 
economics of bioenergetics (hydrogen, methane, bioethanol), an economic prospection at the

108 laboratory level was also developed.

\section{Material and Methods}

$110 \quad$ 2.1. Feedstocks

The CS feedstock obtained from Cuencamé, Durango, Mexico, was dried at $85^{\circ} \mathrm{C}$ during $24 \mathrm{~h}$.

112 Subsequently, dried CS was grinded to a particle size of $180 \mu \mathrm{m}$ using a manual mill.

The characterization of the CS was made following methods previously reported [2]: $\mathrm{pH} 7.54$,

114 total solids (TS) $94.59 \%$, volatile solids (VS) $89.78 \%$ dry basis and ashes $10.22 \%$ dry basis. The main composition of the CS in dry basis $(\mathrm{db})$ was $33.25 \% \mathrm{db}$ cellulose, $24.35 \% \mathrm{db}$ hemicellulose, $24.74 \% \mathrm{db}$

116 lignin, $3.25 \%$ db protein and $10.19 \%$ db extractives. The elemental composition of CS was C-43.84\%, $\mathrm{H}-15.74 \%, \mathrm{O}-39.98 \%$ and $\mathrm{N}-0.44 \%$.

118 The FVW were collected from a local cafeteria (Facultad de Ciencias Químicas, Universidad Autónoma de Nuevo León, Nuevo León, México). FVW were shredded (Hamilton Beach, Food

120 Processor) and dried at $85^{\circ} \mathrm{C}$ during $24 \mathrm{~h}$, and grinded to a particle size of $180 \mu \mathrm{m}$ using a mortar. FVW consisted of (wet weight basis): papaya peels (16.94\%), squash peels (15.57\%), potato

122 peels (17.67\%), spinach stems (20.26\%); parsley stems $(6.71 \%)$, cucumber peels $(5.72 \%)$; melon peels (10.20\%) and apple residues (6.92\%). FVW presented $\mathrm{pH} 5.52$, total solids $10.19 \%$, volatile

124 solids $87.66 \% \mathrm{db}$ and $12.34 \% \mathrm{db}$ of ashes. Further characterization of this material showed as composition of $12.8 \%$ db cellulose, $23.4 \%$ db hemicellulose, $10.26 \%$ db lignin, $12.63 \%$ db protein and

$12638.11 \%$ db extractives. The elemental composition of FVW was C-51.69\%, H-3.43\%, O-42.69\% and $\mathrm{N}-2.19 \%$.

128

\subsection{Dilute acid hydrolysis pretreatment}

130 Dilute acid hydrolysis was evaluated using a $5 \times 2$ general factorial experimental design [16]. The factors were the FVW to CS ratio $\left(0: 1,1: 3,1: 1,3: 1,1: 0 \mathrm{FVW}: \mathrm{CS}_{\mathrm{db}}\right)$ and the type of acid catalyst $132\left(\mathrm{HCl}\right.$ or $\mathrm{H}_{2} \mathrm{SO}_{4}, 0.5 \%$ in volumetric basis). The acid hydrolysis was carried out by triplicate in a 
block digestor (DRB 200, HACH, U.S.A.); the co-substrates preparations were put into $\mathrm{HACH}$

134 tubes at $6.6 \%$ of total solid content and the reaction volume was $5 \mathrm{~mL}$. The hydrolysis time and temperature were set at $120 \mathrm{~min}$ and $120^{\circ} \mathrm{C}[17,18]$. After the hydrolysis pretreatment, solid

136 residues were removed by centrifugation at $10000 \mathrm{~g}, 10 \mathrm{~min}$. Liquid hydrolyzates (LH) were used for sugar analysis (reducing and monomeric sugars) and for the determination of degradation

138 products (furfural; 5-hydroxymethyl-furfural, HMF; total phenolic compounds, TPC; formic acid; acetic acid; propionic acid; succinic acid; lactic acid) according to the method reported by Muñoz-

140 Páez et al [19].

After obtaining the $\mathrm{LH}$, these were processed to remove inhibitory compounds (i.e. HMF, 142 furfural, TPC). For that, the $\mathrm{pH}$ was adjusted to $\mathrm{pH} 10$ by adding powder $\mathrm{Ca}(\mathrm{OH})_{2}$ and continuous stirring for an hour. The formed precipitate was separated by centrifugation at $10000 \mathrm{~g}, 15 \mathrm{~min}$; 144 supernatants were decanted and neutralized to $\mathrm{pH} 7$ by $\mathrm{HCl} 6 \mathrm{M}$ addition [20].

\section{2.3. Dark fermentation of $\mathrm{LH}$}

Hydrogenogenic inoculum was obtained from an anaerobic digester fed with FVW at 30 days of

148 hydraulic retention time, started-up according to the Poggi-Varaldo et al. [21]. To inhibit methaneproducing microflora, the anaerobic sludge was heat-shock treated in boiling water at $96^{\circ} \mathrm{C}$ for 2 $150 \mathrm{~h}[22]$.

The effects of inoculum to substrate ratio (ISR $\left.=\mathrm{gVS}_{\text {inoculum }} \mathrm{g} \mathrm{VS}_{\text {substrate }}{ }^{-1}\right)$ and initial reducing

152 sugars concentration $\left(C_{R S, i}\right)$ on the hydrogen production were evaluated using a $3^{2}$ factorial design. The levels for ISR and $C_{R S, i}$ were $0.8,1.0,1.2$ and 10,13, $16 \mathrm{~g} \mathrm{~L}^{-1}$, respectively.

154 Batch dark fermentation experiments were carried out by duplicate in $120 \mathrm{~mL}$ serum bottles with $70 \mathrm{~mL}$ of working volume. The $C_{R S, i}$ was adjusted by dilution of concentrated LH (ca. $21.13 \mathrm{~g}$

$156 \mathrm{~L}^{-1}$ ) according to the experimental design. The fermentation was supplemented with $0.4 \mathrm{~mL}$ of 200 fold concentrated mineral medium [22]. After inoculation, each bottle was flushed during 3 min with nitrogen to promote anaerobic conditions and sealed with a rubber stopper and aluminum 
rings. The serum bottles were incubated at $35^{\circ} \mathrm{C}$ in a controlled temperature incubator with orbital agitation (150 rpm).

162

\subsection{Analytical methods}

The $\mathrm{pH}$ of co-subtrates was determined according to proceeding described by NMX-AA-25-1984

164 [23]; $5 \mathrm{~g}$ of CS or FVW were diluted with $25 \mathrm{ml}$ of distilled water, stirred for $10 \mathrm{~min}$, and finally measure using a pH-meter (Conductronic PC45, Mexico). Total solids (TS), volatile solids (VS)

166 and ashes were measured according standard methods [24]. Cellulose and insoluble lignin analysis were determined by gravimetric method according to AOAC [25]. The hemicellulose

168 amount was determined by difference between holocellulose and cellulose content. Holocellulose was determined by lignin oxidation using $\mathrm{NaClO}$ according to AOAC modified proceeding [26].

170 Extractives were measured by water extraction in a water bath at $60^{\circ} \mathrm{C}$ during $24 \mathrm{~h}$ [27]. Elemental quantities of carbon, hydrogen, oxygen and nitrogen were determined by organic elemental 172 analyzer (Thermo Scientific Flash 2000, U.S.A.).

The content of total reducing sugars (RS) in LH was determined by 3,5-dinitrosalicylic acid

174 method (dextrose as the standard) [28]. Monomeric sugars were quantified by high performance liquid chromatography (LDC Analytical, U.S.A.) with a Rezex RHM-Monosacharide (300mm x 7.8

$176 \mathrm{~mm}$ ) column and a refractive index detector (Varian Prostar, U.S.A.) with $\mathrm{H}_{2} \mathrm{O}$ as mobile phase. The column temperature and mobile phase flow rate were $65^{\circ} \mathrm{C}$ and $0.6 \mathrm{~mL} \mathrm{~min}^{-1}$, respectively;

178 glucose, xylose and arabinose were used as standards.

The content of total phenolic compounds (TPC) was determined by colorimetric method using

180 Folin Ciocalteu reactive (tannic acid as standard) proposed by Blainski et al. [29]. The subproducts of the acid hydrolysis (furfural, HMF, formic acid, acetic acid, propionic acid, succinic acid, and

182 lactic acid) were determined against standards bought from Sigma Aldrich. These compounds were analyzed using a gas chromatograph (Varian CP 3380, U.S.A.) equipped with a column ZB-

184 FFAP $(15 \mathrm{~m} \times 0.53 \times 1 \mu \mathrm{m})$ and flame ionization detector (FID). The temperatures of the injector 
and the detector were 230 and $280{ }^{\circ} \mathrm{C}$, respectively. The column was first heated to $90{ }^{\circ} \mathrm{C}$ for 3

$186 \mathrm{~min}$, then the temperature was raised gradually to $200^{\circ} \mathrm{C}$ with the step rate of $20^{\circ} \mathrm{C} \mathrm{min}{ }^{-1}$, the temperature was set at $200^{\circ} \mathrm{C}$ for 3 min and finally raised to $250{ }^{\circ} \mathrm{C}$ at $30^{\circ} \mathrm{C} \mathrm{min}-1$, which was then

188 kept for 4 min. Calibration curves were previously developed using pure components.

Hydrogen gas content was determined using a gas chromatograph (Thermo Scientific Trace

190 1310, U.S.A.) equipped with a molecular sieve column (TG-BOND Msieve 5A, $30 \mathrm{~m} \times 0.33 \mathrm{~mm}$ ) and thermal conductivity detector (TCD). The temperatures of the oven, injector and detector were

$192100^{\circ} \mathrm{C}, 150^{\circ} \mathrm{C}$ and $200^{\circ} \mathrm{C}$, respectively. Nitrogen gas was used as carrier gas with a flow rate of $3 \mathrm{~mL} \mathrm{~min}-1$. The amount of total gas produced was determined by acid-brine displacement method.

194 Volatile fatty acids (i.e acetic acid, propionic acid, butyric acid) and solvent (ethanol) composition in the liquid phase were determined by using a gas chromatograph (Thermo Scientific

196 Trace 1310, U.S.A) as described in our previous publication [22] .

\section{2.5. Calculations and statistical analysis}

Hydrolysis potential $\left(H P, \mathrm{~g} \mathrm{~mol}^{-1} \mathrm{H}_{3} \mathrm{O}^{+}\right)$was considered as the quotient of RS concentration, $C_{R S}$ 200 in $\mathrm{g} \mathrm{L}^{-1}$, and the theoretical hydronium concentration of the acid catalyst, $C_{\mathrm{H}_{3} \mathrm{O}^{+}}$as $\mathrm{mol} \mathrm{H}_{3} \mathrm{O}^{+} \mathrm{L}^{-1}$, as described in Eq. 1. According to the concentration $0.5 \%$ volumetric basis for $\mathrm{H}_{2} \mathrm{SO}_{4}$ and $\mathrm{HCl}$ used

202 for the hydrolysis experiments, their respective theoretical hydronium ion concentrations were 0.193 and $0.447 \mathrm{~mol} \mathrm{H}_{3} \mathrm{O}^{+} \mathrm{L}^{-1}$.

$204 \quad H P=\frac{C_{R S}}{C_{H_{3} O^{+}}}$

Reducing sugars production yield, $Y_{R S}(\%)$, was calculated comparing the $\mathrm{C}_{\mathrm{RS}}$ and the total 206 carbohydrates content in the co-substrates (Eq. 2):

$$
Y_{R S}=\frac{C_{R S} \cdot V_{r}}{m_{H} \cdot\left(H_{C S} \cdot C_{c S}+H_{F V W} \cdot C_{F V W}\right)} \cdot 100
$$


208 where $V_{r}$ is the hydrolysis volume (L), $m_{H}$ is the co-substrates mass $(\mathrm{g}), H_{C S}$ and $H_{F V w}$ are the total carbohydrates content (considered as the sum of cellulose, hemicellulose and extractives) in CS

210 and FVW in dry basis $\left(\mathrm{g} \mathrm{g}^{-1}\right)$, respectively, whereas $C_{C S}$ and $C_{F V W}$ are the CS and FVW mass concentration in each co-substrate preparation $\left(\mathrm{g} \mathrm{g}^{-1}\right)$, respectively.

212 The hydrogen cumulative hydrogen production, $H(t)\left(m L H_{2}\right)$, was fitted by the modified Gompertz equation (Eq. 3), to estimate maximum cumulative $\mathrm{H}_{2}$ production, $H_{\max }\left(\mathrm{mL} \mathrm{H} \mathrm{H}_{2}\right)$, 214 maximum $\mathrm{H}_{2}$ production rate, $R_{\max }\left(\mathrm{mL} \mathrm{H}_{2} \mathrm{~h}^{-1}\right)$, and lag time, $\lambda(\mathrm{h})$ [30]:

$$
H(t)=H_{\max } \cdot \exp \left\{-\exp \left[\frac{R_{\max } \cdot e}{H_{\max }}(\lambda-t)+1\right]\right\}
$$

216 where is $t$ is any time $(\mathrm{h})$ and $e$ is 2.718.

The hydrogen molar yield in terms of glucose equivalents consumed ( $Y_{\mathrm{H} 2} \mathrm{~mol} \mathrm{H}_{2} \mathrm{~mol}^{-1}$ glucose $)$ 218 was determined according Eq. 4:

$$
Y_{H_{2}}=\frac{H_{\max } \cdot\left(M W_{\text {glucose }}\right)}{V_{R} \cdot\left(C_{R S_{o}}-C_{R S_{t}}\right) \cdot\left(V_{M}\right) \cdot 1000}
$$

220 where $V_{R}$ is the fermentation volume (L), $C_{R S, i}$ and $C_{R S, f}$ are the initial and final RS concentrations $\left(\mathrm{g} \mathrm{L}^{-1}\right)$, respectively, $M W_{\text {glucose }}$ is the glucose molar weight $\left(180.16 \mathrm{~g} \mathrm{~mol}^{-1}\right), V_{M}$ is

222 the molar volume at standard reference conditions $\left(22.4 \mathrm{~L} \mathrm{~mol} \mathrm{H}_{2}^{-1}\right)$ and 1000 is a volume conversion factor $\left(\mathrm{mL} \mathrm{L}^{-1}\right)$.

224 Analysis of variance (ANOVA) was performed for the experimental designs in the hydrolyzates and hydrogen production, using Design-Expert 6.0 (Design-Ease Inc. Co., Minneapolis, USA).

226 The main effects of the factors evaluated in the experimental designs were calculated according to Montgomery [16]. In the dilute acid hydrolysis experimental design, reducing sugars yield ( $\left.Y_{R S}\right)$,

228 HMF concentration, furfural concentration and TPC were selected to evaluate the main effects, whereas for the dark fermentation experimental design the maximum cumulative hydrogen 230 production $\left(H_{\max }\right)$ and hydrogen molar yield $\left(Y_{\mathrm{H}_{2}}\right)$ were selected. The standard error of the 
experimental designs was calculated from the square root of the mean square of the error divided

232 by the number of experimental repetitions.

\section{2.6. Economic prospection}

The economic prospection accounted the expenses from the main operation stages, and the

236 substances and compounds required for the process. The prospection considered the processing of $1 \mathrm{~kg}$ preparation of 3:1 FVW:CS, including the size reduction, acid hydrolysis and dark

238 fermentation. The size reduction accounted the shredding of FVW in a food processer whereas CS was milled in a vibratory mill. Afterwards, the co-substrates mixture was acid hydrolyzed using $240 \mathrm{HCl}\left(0.5 \%\right.$ volume basis, $\left.2 \mathrm{~h}, 120^{\circ} \mathrm{C}\right)$. The $\mathrm{LH}$ were recovered by centrifugation $(10000 \mathrm{~g}, 10$ min) and were overlimed with $\mathrm{Ca}(\mathrm{OH})_{2}(1 \mathrm{~h}$, room temperature). After centrifugation (ibid.), $\mathrm{LH}$

242 were neutralized using $\mathrm{HCl}(6 \mathrm{M})$. The $\mathrm{LH}$ were fed to a bioreactor with hydrogenogenic inoculum $\left(35^{\circ} \mathrm{C}\right)$. The same mineral composition as in the experiments was considered. Hydrogen content

244 in biogas was $50.1 \%$ and hydrogen yield was $1.91 \mathrm{~mol} \mathrm{H}_{2} \mathrm{~mol}^{-1}$ glucose.

Collection costs of the substrates were retrieved from literature. Thompson and Tyner [31]

246 calculated the collection, baling and transport costs of CS at farms. For the cost of collection and transport of FVW, an average was obtained after the works of Yepes et al. [32] and Mattsson et

248 al. [33], who evaluated the management for FVW valorization in production fields and cities, respectively. Operation costs for the processing of FVW and CS, and hydrogen production, were

250 calculated from energy balances and the Mexican electricity rates at industry [34]. Water cost was taken from Mexican National Water Commission [35]. Chemicals for acid hydrolysis, overliming

252 and mineral medium were taken from different market sources.

The energy calculations from shredding, milling and overliming were obtained as previously

254 described [36]. The energy consumption of acid hydrolysis was determined according to Mafe et al. [37]. The energy balance in dark fermentation reactor was carried out as described by Lübken 
256 et al. [38]. The total process revenue was determined from the market price of $\mathrm{H}_{2}$ and $\mathrm{CO}_{2}$ [39] and their productivities.

258

\section{Results and Discussion}

260

\subsection{Diluted acid hydrolysis pretreatment}

The highest concentrations of RS were obtained at 1:0 FVW:CS ratio, being 19.32 and $27.32 \mathrm{~g}$

$262 \mathrm{~L}^{-1}$ for $\mathrm{H}_{2} \mathrm{SO}_{4}$ and $\mathrm{HCl}$, respectively (Fig. $1 \mathrm{~A}$ ), probably as a consequence of a number of factors such as: a greater digestibility of FVW over CS, heterogeneous composition of FVW, lower lignin 264 content and lower degradation temperature [9]. Regarding the co-substrate preparations, the maximum RS were 24.69 and $17.99 \mathrm{~g} \mathrm{~L}^{-1}$ for $\mathrm{HCl}$ and $\mathrm{H}_{2} \mathrm{SO}_{4}$, respectively, obtained from the 3:1 266 FVW:CS ratio.

\section{PLEASE INSERT FIGURE 1}

270 The $\mathrm{HCl}$ as acid catalyst presented higher $\mathrm{RS}$ production than $\mathrm{H}_{2} \mathrm{SO}_{4}$ at each co-substrate ratio, probably influenced by its 2.32 times higher concentration of hydronium ion than $\mathrm{H}_{2} \mathrm{SO}_{4}$ treatments.

272 However, when observing the $\mathrm{HP}$ (Fig. 1B), $\mathrm{H}_{2} \mathrm{SO}_{4}$ was better than $\mathrm{HCl}$ in achieving a $\mathrm{HP}$ of 100.33 $\mathrm{g} \mathrm{mol}^{-1} \mathrm{H}_{3} \mathrm{O}^{+}$at 1:0 FVW:CS ratio, versus $61.13 \mathrm{~g} \mathrm{~mol}^{-1} \mathrm{H}_{3} \mathrm{O}^{+}$for $\mathrm{HCl}$ at same ratio. Hilpmann et

274 al. [40] observed that hydronium concentration is one of the several factors that have influence on the efficiency of the acid hydrolysis of xylan. They found that hydronium concentrations lower than

$2760.1 \mathrm{M}$ presented yields below $86 \%$, whereas hydronium concentrations higher than $0.1 \mathrm{M}$ promoted yields close to $100 \%$. It is worth noticing that due to the lower corrosivity of $\mathrm{H}_{2} \mathrm{SO}_{4}$

278 compared to $\mathrm{HCl}$ or $\mathrm{HNO}_{3}$, it has been the most used catalyst in hydrolysis processes of lignocellulosic wastes $[41,42]$.

280 The main effects analysis (Fig. 2) showed that the maximum $Y_{R S}$ was observed at 1:0 FVW:CS ratio, which corroborated the ease of degradation of FVW and also demonstrated a correlation 
282 amidst the contents of FVW and $Y_{R S}$ (Fig. 2A). Regarding the type of acid catalysts influence on $Y_{R S}, \mathrm{HCl}$ was superior over $\mathrm{H}_{2} \mathrm{SO}_{4}(\mathrm{Fig} 2 \mathrm{~B})$, thus the combination of high contents of $\mathrm{FVW}$ and

$284 \mathrm{HCl}$ is advisable to promote high $Y_{R S}$. The ANOVA (Table S1) of $Y_{R S}$ showed that the model, the co-substrate ratios, the acid catalyst and their interaction were significant $(p<0.0053)$. The $R^{2}$ 286 and $\mathrm{R}^{2}$ adj were 0.8411 and 0.7696 , respectively.

\section{PLEASE INSERT FIGURE 2}

290 Regarding the production and distribution of monosaccharides, noticeable differences were observed amidst the type of catalyst as shown in Fig. 3. When using $\mathrm{HCl}$ as catalyst (Fig. 3A),

292 maximal concentrations of glucose were obtained at 3:1 FVW:CS ratio $\left(10.02 \mathrm{~g} \mathrm{~L}^{-1}\right)$, and at 1:3 FVW:CS for xylose $\left(8.41 \mathrm{~g} \mathrm{~L}^{-1}\right)$. No particular trends were appreciated after $\mathrm{H}_{2} \mathrm{SO}_{4}$ treatment (Fig.

294 3B). In the experiments with $\mathrm{HCl}$, it was observed that the ratios with higher CS content presented higher xylose concentrations, whereas those ratios with higher FVW presented higher glucose

296 concentrations. This difference is interesting and has also been reported elsewhere. For instance, Zu et al. [43] evaluated the CS hydrolysis with $\mathrm{HCl}$ as acid catalyst and found that xylose yield 298 was also higher than that of glucose (20.44 and $1.82 \mathrm{~g}$ per $100 \mathrm{graw}$ material, respectively) at $120^{\circ} \mathrm{C}$, $40 \mathrm{~min}$ and $1 \% \mathrm{HCl}$. Similarly, Cao et al. [44] found higher xylose concentrations than glucose

300 (6.25 and $1.68 \mathrm{~g} \mathrm{~L}^{-1}$, respectively) when assessing the $\mathrm{CS}$ acid hydrolysis with $\mathrm{H}_{2} \mathrm{SO}_{4}$ at $121{ }^{\circ} \mathrm{C}$, $105 \mathrm{~min}$, and $0.25 \% \mathrm{H}_{2} \mathrm{SO}_{4}$, ascribing this phenomenon to the easier hemicellulose solubilization 302 than cellulose by acid catalyst in this particular substrate.

306 An undesirable trait about the acid hydrolysis processes is the concomitant degradation of hydrolyzed carbohydrates into compounds such as furfural and HMF, and the lignin degradation 
308 into acetic acid and phenolic compounds, which altogether act as inhibitors to microbial growth $[5,41]$. In our experiments, there were significant differences $(p<0.0085)$ of both the acid catalysts

310 and the FVW:CS ratio on HMF, furfural and TPC production (Table S2, Table S3 and Table S4, respectively). Fig. 4 shows that for HMF and TPC, their concentrations were higher for $\mathrm{HCl}$ and

312 as FVW increased its proportion. Regarding furfural, $\mathrm{HCl}$ also produced higher concentrations than $\mathrm{H}_{2} \mathrm{SO}_{4}$, although $\mathrm{FVW}$ effect was not as evident as in HMF and TPC showing a maximum at

$314 \quad 1: 3$ and a minimum at 3:1 FVW:CS ratios. These observations have some relation to that observed for $Y_{R S}$, and the respective explanation is also applicable to this case: $\mathrm{FVW}$ is a substrate much

316 easier to degrade, and $\mathrm{HCl}$ provides higher $\mathrm{H}^{+}$concentration than $\mathrm{H}_{2} \mathrm{SO}_{4}$ when both substances are assayed at the same volumetric concentration.

\section{PLEASE INSERT FIGURE 4}

The concentrations of HMF, furfural and TPC in our experiments (Table 1) were lower than the 322 inhibitory concentrations $\left(<1 \mathrm{~g} \mathrm{~L}^{-1}\right)$ reported for dark fermentation of mixed cultures, except for the hydrolyzates at 1:0 FVW:CS ratio and $\mathrm{HCl}$ [45]. Moreover, when two or more inhibitors are present

324 in the substrate medium, inhibition concentrations may be considerably lower, yet not consistent data has been found amidst literature. For instance, Kumar et al. [46] found that at $0.69 \mathrm{~g} \mathrm{HMF} \mathrm{L'}$

$326{ }^{1}$ and $12 \mathrm{~g}$ formic acid $\mathrm{L}^{-1}$ concentrations, microbial growth and hydrogen production were inhibited. On the other hand, Zheng et al. [18] reported that up to $4 \mathrm{~g} \mathrm{~L}^{-1}$ of HMF or furfural and $6 \mathrm{~g}$ acetic 328 acid L-1 inhibited microbial metabolism. On their behalf, Muñoz-Páez et al. [19] observed that individual concentrations of furfural and HMF up to 1 and $0.09 \mathrm{~g} \mathrm{~L}^{-1}$, respectively, were even 330 beneficial for biohydrogen production; yet when concomitantly present, these have inhibited $10 \%$ the hydrogen production even at low concentrations as 0.10 and $0.02 \mathrm{~g} \mathrm{~L}^{-1}$ for furfural and HMF,

332 respectively. In general, the most important inhibitor has been suggested to be HMF, and it should be considered that concentrations above $1 \mathrm{~g} \mathrm{~L}^{-1}$ in hydrolyzates have reduced the yield in 
334 hydrogen bioproduction [5]. Indeed, except for one of our assays, such value was not reached, pointing out that our hydrolyzates would be suitable for dark fermentation or anaerobic digestion $336[45]$.

\section{PLEASE INSERT TABLE 1}

340 It is important to note that for both $\mathrm{HCl}$ and $\mathrm{H}_{2} \mathrm{SO}_{4}$ at 1:0 FVW:CS assays (Fig. 3), no xylose content was detected, most likely due to its conversion into furfural and subsequent transformation

342 into formic, lactic and succinic acids [47]. Indeed, the sum of these latter compounds was around $9.5 \mathrm{~g} \mathrm{~L}^{-1}$, a concentration comparable to that of xylose at FVW:CS ratio of 1:3.

344 Since the acid hydrolysis of 3:1 FVW:CS with $\mathrm{HCl}$ catalyst (Fig.3) showed a balanced distribution of glucose, xylose and arabinose, as well as high RS concentration, dark fermentation

346 was developed in the next section using the hydrolyzates from such conditions. Despite the low concentration of inhibitors, the liming treatment was applied to the hydrolyzates to avoid possible

348 interactions of any kind during the hydrogen production. The overliming treatment decreased both the reducing sugars by $11.71 \%$ ( 24.00 to $21.19 \mathrm{~g} \mathrm{~L}^{-1}$ ) and the TPC by $26.4 \%$ ( 1.06 to $0.78 \mathrm{~g} \mathrm{~L}^{-1}$ )

350 in $26.41 \%$. This diminution of RS was comparable with the $9.1 \%$ reduction observed by Chang et al. [20] when rice husk $\mathrm{HCl}$ hydrolyzates were overlimed. The removals of TPC and HMF over

$35220 \%$ are according to expected, whereas it is common that some organic acids might not be reduced by overliming [48].

354

\subsection{Dark fermentation of $L H$}

356 The highest $H_{\max }(212 \mathrm{~mL} \mathrm{H})$ and $R_{\max }\left(8.83 \mathrm{~mL} \mathrm{H}_{2} \mathrm{~h}^{-1}\right)$ were obtained for ISR 1.2 and $C_{R S, i}$, of 13 $\mathrm{g} \mathrm{L}^{-1}$ (Fig. 5, Table 2). Comparing the cumulative hydrogen production against literature is intricate 358 due to the different reported operation conditions. For mixed cultures, Datar et al. [8] demonstrated a cumulative hydrogen volume of $4138 \mathrm{~mL}$ when using CS hydrolyzates $\left(10 \mathrm{~g} \mathrm{~L}^{-1}\right)$ in dark 
360 fermentation by anaerobic heat-treated sludge $\left(105^{\circ} \mathrm{C}, 2 \mathrm{~h}\right)$ in a $1250 \mathrm{~mL}$ CSTR. Their volumetric hydrogen productivity, $3310 \mathrm{~mL} \mathrm{H}_{2} \mathrm{~L}^{-1}$ reactor was $13 \%$ higher than our best result of $2933 \mathrm{~mL} \mathrm{H}_{2} \mathrm{~L}^{-}$

$362{ }^{1}{ }_{\text {reactor }}$ at ISR 1.2 and $13 \mathrm{~g} \mathrm{RS} \mathrm{L}^{-1}$ (Table 3). However, in their experiments the longer lag time obtained, $38 \mathrm{~h}$, was ascribed to the presence of inhibitory compounds such as HMF and furfural 364 obtained after extreme hydrolysis conditions (acid steam-explosion $1.2 \% \mathrm{H}_{2} \mathrm{SO}_{4}, 200{ }^{\circ} \mathrm{C}, 1 \mathrm{~min}$ ). The longest lag time registered in our experiments was $22.5 \mathrm{~h}$ for the assay with the lowest 366 inoculum load (ISR 0.8) and the highest substrate amounts (RS $16 \mathrm{~g} \mathrm{~L}^{-1}$ ), which could have been an indicative of a slower adaptation of hydrogen-microbial producers to substrate [20].

\section{PLEASE INSERT FIGURE 5}

370 PLEASE INSERT TABLE 2

\section{PLEASE INSERT TABLE 3}

The ANOVA (Table S5 and Table S6) of this experiment showed that $C_{R S, i}$ had significant 374 effects on both $H_{\max }$ and $Y_{\mathrm{H} 2}$, whereas the ISR did not present significant effects on neither response variables in the studied operation range. The main effects of the $C_{R S, i}$ on the $H_{\max }$ (Fig.

$3766 \mathrm{~A})$ demonstrated that $10 \mathrm{~g} \mathrm{~L}^{-1}$ presented the lowest average hydrogen production $\left(183 \mathrm{~mL} \mathrm{H}_{2}\right.$ ), whereas using 13 or $16 \mathrm{~g} \mathrm{~L}^{-1}$ presented higher values (ca. $202 \mathrm{~mL} \mathrm{H}_{2}$ ). Oppositely, the main effects

378 on $Y_{\mathrm{H} 2}$ (Fig. $\left.6 \mathrm{~B}\right)$ were higher at $\mathrm{C}_{\mathrm{RS}, \mathrm{i}} 10 \mathrm{~g} \mathrm{~L}^{-1}\left(2.2 \mathrm{~mol} \mathrm{H}_{2}\right.$ mol glucose $\left.^{-1}\right)$ than at 13 and $16 \mathrm{~g} \mathrm{~L}^{-1}(1.8$ and $1.9 \mathrm{~mol} \mathrm{H}_{2} \mathrm{~mol}$ glucose ${ }^{-1}$, respectively). This was in accordance to the reducing sugars 380 consumption (Table 3): at $C_{R S, i}$ of 10 and $13 \mathrm{~g} \mathrm{~L}^{-1}$ the RS consumption was higher than $94.9 \%$, whereas at $16 \mathrm{~g} \mathrm{~L}^{-1}$, it was close to $81 \%$, except for the experiment with ISR 0.8 that presented

382 ca. $70 \%$ consumption, indicating the possible inhibition by substrate or metabolites. Therefore, in terms of $H_{\max }$ and $Y_{\mathrm{H} 2}$, It may be drawn that $C_{R S, i}$ of 10 and $13 \mathrm{~g} \mathrm{~L}^{-1}$ may be the best options for

384 conducting dark fermentation of hydrolyzates. Fangkum et al. [6] reported an increase in cumulated hydrogen production (42 to $92 \mathrm{~mL} \mathrm{H}_{2}$ ) when the initial concentration of fermentable 
386 sugars increased from 5 to $10 \mathrm{~g} \mathrm{~L}^{-1}$; yet when initial concentration of sugars exceeded $20 \mathrm{~g} \mathrm{~L}^{-1}$, cumulated hydrogen production decreased mainly due to the accumulation of organic fatty acids,

388 which was reflected as a drop in $\mathrm{pH}$, causing bacterial growth inhibition. In our experiments, the final $\mathrm{pH}$ dropped as $C_{R S, I}$ increased, being the lowest of 5.17 when using RS $16 \mathrm{~g} \mathrm{~L}^{-1}$ at ISR 0.8 390 (Table 3).

\section{PLEASE INSERT FIGURE 6}

394 Comparing our highest molar yields of 1.9-2.3 mol $\mathrm{H}_{2}$ mol glucose ${ }^{-1}$ amidst the range $0.8-1.2$ ISR (Table 3) to literature (Table 4), ours were higher than some using pure cultures as in the 396 case of Pattra et al. [49] who reported $1.73 \mathrm{~mol} \mathrm{H}_{2}$ mol glucose $^{-1}$ by Clostridium butyricum when fermenting sugarcane acid hydrolyzates at higher concentration $\left(20 \mathrm{~g} \mathrm{~L}^{-1}\right)$; or as in the case of

398 Cao et al. [44] who obtained $2.24 \mathrm{~mol} \mathrm{H}_{2}$ mol glucose $^{-1}$ by Thermoanaerobacterium thermosaccharolyticum W16 fermenting $12 \mathrm{~g} \mathrm{~L}^{-1}$ of sugars from corn hydrolyzates at thermophilic 400 temperatures $\left(60^{\circ} \mathrm{C}\right)$. Using microbial consortia, Zhang et al. [50] obtained low hydrogen yields ( $0.35 \mathrm{~mol} \mathrm{H}_{2} \mathrm{~mol}_{\text {glucose }}{ }^{-1}$ ) with an anaerobic granular sludge at $37^{\circ} \mathrm{C}$, whereas at $55^{\circ} \mathrm{C}$ the

402 hydrogen yield was increased to $1.39 \mathrm{~mol} \mathrm{H}_{2}$ mol glucose $^{-1}$. The main difference from our experiments against those listed in Table 4 was our noticeably higher ISR. Indeed, the next highest

404 ISR, 0.4, was that from Datar et al. [8], who indeed obtained the highest $Y_{\text {H2. }}$ Our results have demonstrated that it was feasible to hydrolyze preparations of FVW and CS, and to use the sugars 406 released to achieve competent batch hydrogen production by microbial consortia.

410 Regarding the metabolites produced, in all the experiments butyrate was the most abundant, followed by acetate and lastly by propionate. High butyrate concentrations are indicative of the 
412 predominance of the butyrogenic pathway in this dark fermentation hydrogen production [5]. On the other hand, low propionate concentrations is advantageous since it may indicate low presence

414 of propionogenic microorganisms that use $\mathrm{H}_{2}$ as electron donor [51]. Low ethanol concentrations are attributed to a low partial pressure effect due to the frequent hydrogen depressurization. Since

416 a high variation in the partial pressure may change the route of metabolites production (i.e. solvents such as ethanol, acetone or butanol instead of VFA) [7,52].

418

\subsection{Economic prospection}

420 A net benefit of 0.009 USD per kg of co-substrates (wet basis) processed was observed (Table 5). The total costs were 0.029 USD/kg (including energy, water and chemicals), whereas the 422 revenue for $\mathrm{H}_{2}$ and $\mathrm{CO}_{2}$ produced was $0.038 \mathrm{USD} / \mathrm{kg}$. The costs were distributed as $54 \%$ related to FVW and CS supply, $26 \%$ due to substances and compounds, and the remaining $20 \%$ to

424 electricity consumption. From this analysis, it is evident that waste biomass long before considered to be low cost [53] is not necessarily so. Different alternatives have been implemented to reduce

426 such related production costs, such as government funding and subsidies [39].

The unit costs for $\mathrm{H}_{2}$ and $\mathrm{CO}_{2}$ considering a revenue-based allocation were 2.05 and 0.3

$428 \mathrm{USD} / \mathrm{m}^{3}$, respectively. The market price of $\mathrm{H}_{2}$ and $\mathrm{CO}_{2}$ are 2.7 and $0.3 \mathrm{USD} / \mathrm{m}^{3}$, which indicates the profitability in hydrogen production of $24 \%$. Indeed, hydrogen cost was comparable to other

430 works in literature using different substrates. For instance, Han et al. [54] reported a cost of 2.29 USD $/ \mathrm{m}^{3} \mathrm{H}_{2}$ from the techno-economic analysis of hydrogen production from food waste by

432 integrated solid state fermentation and dark fermentation. The plant capacity was proposed to be 10 ton/d, and yield was $52.4 \mathrm{~mL} \mathrm{H}_{2} / \mathrm{g}$ food waste. Using bread waste, Han et al. [39] reported a

434 production cost of $1.34 \mathrm{USD} / \mathrm{m}^{3}$ for the continuous hydrogen production in a 2 ton/d CSTR.

The production of hydrogen from hydrolyzates of FVW and CS has shown a promissory 436 alternative for the development of biorefinery models. Still, as hydrogen production finds alternatives of production from different substrates, biorefinery configurations and operation 
438 conditions, it is becoming necessary to improve economic evaluations. We envisage areas of opportunity that will have consequences both for revenues and costs. For instance, the process

440 profitability can be improved if the sub-products as organic acids and solvents from dark fermentation are further processed (e.g. hydrogen production by the photofermentation or

442 methane production by anaerobic digestion) or marketed, as in the case of un-solubilized biomass that could be sold as biofertilizer. On the other hand, equipment, construction, and other operating

444 costs such gas compression, salaries and taxes will increase production costs [55].

$446 \quad$ PLEASE INSERT TABLE 5

448 4. Conclusion

The main conclusions of this work were several and noticeworthy. They arranged according to the 450 principal sections of the research, as follows:

i) Hydrolysis. $\mathrm{HCl}$ as acid catalyst was superior than $\mathrm{H}_{2} \mathrm{SO}_{4}$ in terms of amount and quality of hydrolyzates, and the 3:1 $\mathrm{FVW}: \mathrm{CS}$ ratio using $\mathrm{HCl}$ resulted in the highest production of reducing sugars in a balanced distribution of the monosaccharides glucose, xylose and arabinose.

ii) Dark fermentation. The FVW:CS sugar-rich hydrolyzates were efficiently fermented. Moreover, the initial concentration of reducing sugars had important and significant effects both on maximum hydrogen production and yield. $\mathrm{H}_{2}$ production was not dependent by inoculum to substrate ratio in the range 0.8 to $1.2 \mathrm{~g} \mathrm{VS}_{\text {inoculum }} \mathrm{g} \mathrm{VS}_{\text {substrate }}{ }^{-}$ 1. Concentrations of 10 and $13 \mathrm{~g} \mathrm{~L}^{-1}$ are suitable for conducting competent dark fermentation of hydrolyzates.

iii) Economic prospection. Hydrogen production presented economic benefits, such as net revenues of 0.009 USD per kg of co-substrates (wet basis) processed and $\mathrm{H}_{2}$ unit cost 
below its market price, resulting in $24 \%$ profitability of hydrogen production. The main costs were associated to FVW and CS supply.

Finally, the production of hydrogen from hydrolyzates of FVW and CS, as alternative to mono-

466 substrates fermentation, has shown a promissory option for the development of biorefinery models.

\section{Acknowledgements}

The authors express their gratitude to Dr. Eduardo Soto Regalado and Dr. Felipe Cerino Córdova

470 for supporting the project (02-106534-PST-15/123), and to Dr. Refugio Bernardo García Reyes, Dr. Luis H. Alvarez, Chem. Eng. Gustavo Gerardo Medina Mendoza and Damián Isaac Peña472 Ramírez for their support in analysis determination. Santiago Rodríguez-Valderrama thanks Consejo Nacional de Ciencia y Tecnología (Conacyt) for the Scholarship No. 714579.

\section{References}

[1] M.E. Nissilä, C. Lay, J.A. Puhakka, Dark fermentative hydrogen production from lignocellulosic hydrolyzates-A

[2] C. Escamilla-Alvarado, T. Ponce-Noyola, E. Ríos-Leal, H.M. Poggi-Varaldo, A multivariable evaluation of biohydrogen production by solid substrate fermentation of organic municipal wastes in semi-continuous and batch operation, Int. J. Hydrogen Energy. 38 (2013) 12527-12538. doi:10.1016/j.ijhydene.2013.02.124.

482 [3] SAGARPA, Planeación agrícola nacional 2017-2030, 2017.

[4] I. Valdez-Vazquez, J.A. Acevedo-Benítez, C. Hernández-Santiago, Distribution and potential of bioenergy resources from agricultural activities in Mexico, Renew. Sustain. Energy Rev. 14 (2010) 2147-2153. doi:10.1016/j.rser.2010.03.034.

486 [5] R.R. Gonzales, P. Sivagurunathan, S.-H. Kim, Effect of severity on dilute acid pretreatment of lignocellulosic biomass and the following hydrogen fermentation, Int. J. Hydrogen Energy. 41 (2016) 21678-21684. doi:10.1016/j.ijhydene.2016.06.198.

[6] A. Fangkum, A. Reungsang, Biohydrogen production from sugarcane bagasse hydrolysate by elephant dung: Effects of initial pH and substrate concentration, Int. J. Hydrogen Energy. 36 (2011) 8687-8696. doi:10.1016/j.ijhydene.2010.05.119.

492 [7] Y.M. Wong, T.Y. Wu, J. Ching-Juan, A review of sustainable hydrogen production using seed sludge via dark fermentation, Renew. Sustain. Energy Rev. 34 (2014) 471-482. doi:10.1016/j.rser.2014.03.008.

494 [8] R. Datar, J. Huang, P.C. Maness, A. Mohagheghi, S. Czernik, E. Chornet, Hydrogen production from the fermentation of corn stover biomass pretreated with a steam-explosion process, Int. J. Hydrogen Energy. 32

496 (2007) 932-939. doi:10.1016/j.ijhydene.2006.09.027.

[9] A. Razaghi, O.P. Karthikeyan, H.. Nguyen Hao, K. Heinamm, Hydrolysis treatments of fruit and vegetable 
waste for production of biofuel precursors, Bioresour. Technol. 217 (2016) 100-103.

doi:10.1016/j.biortech.2016.03.041.

$500 \quad$ [10] W. Wang, L. Xie, G. Luo, Q. Zhou, Enhanced fermentative hydrogen production from cassava stillage by codigestion: The effects of different co-substrates, Int. J. Hydrogen Energy. 38 (2013) 6980-6988.

502 doi:10.1016/j.ijhydene.2013.04.004.

[11] W. Wang, L. Xie, J. Chen, G. Luo, Q. Zhou, Biohydrogen and methane production by co-digestion of cassava stillage and excess sludge under thermophilic condition, Bioresour. Technol. 102 (2011) 3833-3839. doi:10.1016/j.biortech.2010.12.012.

506

[12] L.R. Miramontes-Martínez, R. Gomez-Gonzalez, J.E. Botello-Alvarez, C. Escamilla-Alvarado, A. AlbalateRamírez, P. Rivas-Garcia, Semi-continuous anaerobic co-digestion of vegetable waste and cow manure: a study of process stabilization, Rev. Mex. Ing. Química. 19 (2020) 1117-1134. http://www.redalyc.org/articulo.oa?id=62029966013.

[13] S.H. Kim, S.K. Han, H.S. Shin, Feasibility of biohydrogen production by anaerobic co-digestion of food waste and sewage sludge, Int. J. Hydrogen Energy. 29 (2004) 1607-1616. doi:10.1016/j.jjhydene.2004.02.018. A. Sultana, A. Kumar, Optimal configuration and combination of multiple lignocellulosic biomass feedstocks delivery to a biorefinery, Bioresour. Technol. 102 (2011) 9947-9956. doi:10.1016/j.biortech.2011.07.119. A.L. Borrion, M.C. McManus, G.P. Hammond, Environmental life cycle assessment of bioethanol production from wheat straw, Biomass and Bioenergy. 47 (2012) 9-19. doi:10.1016/j.biombioe.2012.10.017.

516 [16] D.C. Montgomery, Design and analysis of experiments, in: 2004: pp. 194-201.

[17] S. Kumar, P. Dheeran, S.P. Singh, I.M. Mishra, D.K. Adhikari, Kinetic studies of two-stage sulphuric acid hydrolysis of sugarcane bagasse, Renew. Energy. 83 (2015) 850-858. doi:10.1016/j.renene.2015.05.033.

[18] Y. Zheng, C. Lee, C. Yu, Y.S. Cheng, R. Zhang, B.M. Jenkins, J.S. VanderGheynst, Dilute acid pretreatment and fermentation of sugar beet pulp to ethanol, Appl. Energy. 105 (2013) 1-7. doi:10.1016/j.apenergy.2012.11.070.

522

K.M. Muñoz-Páez, E.L. Alvarado-Michi, G. Buitrón, I. Valdez-Vazquez, Distinct effects of furfural, hydroxymethylfurfural and its mixtures on dark fermentation hydrogen production and microbial structure of a mixed culture, Int. J. Hydrogen Energy. 4 (2019) 2289-2297. doi:10.1016/j.jhydene.2018.04.139.

[20] A.C.C. Chang, Y.H. Tu, M.H. Huang, C.H. Lay, C.Y. Lin, Hydrogen production by the anaerobic fermentation from acid hydrolyzed rice straw hydrolysate, Int. J. Hydrogen Energy. 36 (2011) 14280-14288. doi:10.1016/j.jjhydene.2011.04.142.

H.M. Poggi-Varaldo, L. Valdés, F. Esparza-García, G. Fernández-Villagómez, Solid substrate anaerobic codigestion of paper mill sludge, biosolids, and municipal solid waste, Water Sci. Technol. 35 (1997) 197-204. http://wst.iwaponline.com/content/35/2-3/197.abstract.

[22] S. Rodríguez-Valderrama, C. Escamilla-Alvarado, H.J. Amezquita-Garcia, J.J. Cano-Gómez, J.P. Magnin, P. Rivas-García, Evaluation of feeding strategies in upflow anaerobic sludge bed reactor for hydrogenogenesis at psychrophilic temperature, Int. J. Hydrogen Energy. 44 (2019) 12346-12355. doi:10.1016/j.ijhydene.2018.09.215.

[23] NMX-AA-25-1984, Norma Mexicana NMX-AA-25-1984. Protección al ambiente-Contaminación del sueloresiduos sólidos-determinación del pH-Método potenciométrico, Norma Mex. (1992) 4-5.

[24] APHA/AWWA/WEF, Standard methods for the examination of water and wastewater, Am. Public Heal. Assoc. 538 (2005). doi:ISBN 9780875532356.

[25] AOAC, Official methods of analysis, Assoc. Off. Agric. Chem. Washington, D.C. (1992). 
540 [26] C. Escamilla-Alvarado, H.M. Poggi-Varaldo, T. Ponce-Noyola, E. Ríos-Leal, I. Robles-Gonzalez, N. Rinderknecht-Seijas, Saccharification of fermented residues as integral part in a conceptual hydrogen-

542 producing biorefinery, Int. J. Hydrogen Energy. 40 (2015) 17200-17211. doi:10.1016/j.jijhydene.2015.06.164.

[27] A. Sluiter, R. Ruiz, C. Scarlata, J. Sluiter, D. Templeton, Determination of extractives in biomass, NREL. (2008).

[28] G.L. Miller, Use of dinitrosalicylic acid reagent for determination of reducing sugar, Anal. Chem. 31 (1959) 426-428. doi:10.1021/ac60147a030.

[29] A. Blainski, G.C. Lopes, J.C. Palazzo de Mello, Application and analysis of the Folin Ciocalteu method for the determination of the total phenolic content from Limonium Brasiliense L., Molecules. 18 (2013) 6852-6865. doi:10.3390/molecules18066852.

550 [30] M.H. Zwietering, I. Jongenburger, F.M. Rombouts, K. Van 't Riet, Modeling of the bacterial growth curve, Appl. Environ. Microbiol. 56 (1990) 1875-1881.

552 [31] J.L. Thompson, W.E. Tyner, Corn stover for bioenergy production: Cost estimates and farmer supply response, Biomass and Bioenergy. 62 (2014) 166-173. doi:10.1016/j.biombioe.2013.12.020.

[32] S.M. Yepes, L.J. Montolla Naranjo, S. Orozco, Agroindustrial waste valorization-fruits-in-Medellin and the south of Valle de Aburrá, Colombia, Rev.Fac.Nal.Agr.Medellín. 61 (2008) 4422-4431.

[33] L. Mattsson, H. Williams, J. Berghel, Waste of fresh fruit and vegetables at retailers in Sweden - Measuring and calculation of mass, economic cost and climate impact, Resour. Conserv. Recycl. 130 (2018) 118-126. doi:10.1016/j.resconrec.2017.10.037.

[34] Comisión Federal de Electricidad, Tarifas CFE industrial, (2020). https://app.cfe.mx/Aplicaciones/CCFE/Tarifas/TarifasCREIndustria/Tarifas/GranDemandaMTO.aspx (accessed May 30, 2020).

562

[35] Conagua, Tarifas de agua, México, (2020). http://sina.conagua.gob.mx/sina/tema.php?tema=tarifas\&ver=reporte\&o=0\&n=nacional (accessed May 30,

564 2020).

[36] S. Rodríguez-Valderrama, Enfoque de biorrefinería para la producción de hidrógeno y metano a partir de 566 residuos orgánicos, Universidad Autónoma de Nuevo León, 2018.

[37] O.A.T. Mafe, S.M. Davies, J. Hancock, C. Du, Development of an estimation model for the evaluation of the energy requirement of dilute acid pretreatments of biomass, Biomass and Bioenergy. 72 (2015) 28-38. doi:10.1016/j.biombioe.2014.11.024.

570

M. Lübken, M. Wichern, M. Schlattmann, A. Gronauer, H. Horn, Modelling the energy balance of an anaerobic digester fed with cattle manure and renewable energy crops, Water Res. 41 (2007) 4085-4096.

572 doi:10.1016/j.watres.2007.05.061.

[39] W. Han, Y.Y. Hu, S.Y. Li, F.F. Li, J.H. Tang, Biohydrogen production from waste bread in a continuous stirred tank reactor: A techno-economic analysis, Bioresour. Technol. 221 (2016) 318-323. doi:10.1016/j.biortech.2016.09.055.

576 [40] G. Hilpmann, N. Becher, F.A. Pahner, B. Kusema, P. Mäki-Arvela, R. Lange, D.Y. Murzin, T. Salmi, Acid hydrolysis of xylan, Catal. Today. 259 (2014) 376-380. doi:10.1016/j.cattod.2015.04.044.

578 [41] G.S. Hutomo, A. Rahim, S. Kadir, The effect of sulfuric and hydrochloric acid on cellulose degradation from pod husk cacao, Int. J. Curr. Microbiol. Appl. Sci. 4 (2015) 89-95.

580 [42] H. Argun, G. Onaran, Glucose and 5-hydroxymethylfurfural production from cellulosic waste by sequential alkaline and acid hydrolysis, Renew. Energy. 96 (2016) 442-449. doi:10.1016/j.renene.2016.04.082. 
582 [43] S. Zu, W. zhi Li, M. Zhang, Z. Li, Z. Wang, H. Jameel, H. min Chang, Pretreatment of corn stover for sugar production using dilute hydrochloric acid followed by lime, Bioresour. Technol. 152 (2014) 364-370.

584 doi:10.1016/j.biortech.2013.11.034.

[44] G. Cao, N. Ren, A. Wang, D.J. Lee, W. Guo, B. Liu, Y. Feng, Q. Zhao, Acid hydrolysis of corn stover for biohydrogen production using Thermoanaerobacterium thermosaccharolyticum W16, Int. J. Hydrogen Energy. 34 (2009) 7182-7188. doi:10.1016/j.jijhydene.2009.07.009.

588 [45] M. Quéméneur, J. Hamelin, A. Barakat, J.P. Steyer, H. Carrre, E. Trably, Inhibition of fermentative hydrogen production by lignocellulose-derived compounds in mixed cultures, Int. J. Hydrogen Energy. 37 (2012) 31503159. doi:10.1016/j.ijhydene.2011.11.033.

[46] G. Kumar, H.C. Cheon, S.H. Kim, Effects of 5-hydromethylfurfural, levulinic acid and formic acid, pretreatment byproducts of biomass, on fermentative $\mathrm{H}_{2}$ production from glucose and galactose, Int. J. Hydrogen Energy. 39 (2014) 16885-16890. doi:10.1016/j.ijhydene.2014.08.063.

594

[47] M. Möller, U. Shröder, Hydrothermal production of furfural from xylose and xylan as model compounds for hemicelluloses, RSC Adv. 3 (2013) 22253-22260. doi:10.1039/c3ra43108h.

596

[48] S. Larsson, A. Reimann, N.O. Nilverbrant, L. Jönsson, Comparison of different methods for the detoxification of lignocellulose hydrolyzates of Spruce, Appl. Biochem. Biotechnol. 77 (1999) 2273-2289.

598

[49] S. Pattra, S. Sangyoka, M. Boonmee, A. Reungsang, Bio-hydrogen production from the fermentation of sugarcane bagasse hydrolysate by Clostridium butyricum, Int. J. Hydrogen Energy. 33 (2008) 5256-5265.

600

[50] K. Zhang, N. Ren, A. Wang, Fermentative hydrogen production from corn stover hydrolyzate by two typical

602 seed sludges : Effect of temperature, Int. J. Hydrogen Energy. 40 (2015) 3838-3848. doi:10.1016/j.jjhydene.2015.01.120.

604

M.A.Z. Bundhoo, R. Mohee, Inhibition of dark fermentative bio-hydrogen production: A review, Int. J. Hydrogen Energy. 41 (2016) 6713-6733. doi:10.1016/j.ijhydene.2016.03.057.

606

M.A. Hernández, M. Rodríguez Susa, Y. Andres, Use of coffee mucilage as a new substrate for hydrogen production in anaerobic co-digestion with swine manure, Bioresour. Technol. 168 (2014) 112-118.

608 doi:10.1016/j.biortech.2014.02.101.

[53] H.M. Poggi-Varaldo, K.M. Munoz-Paez, C. Escamilla-Alvarado, P.N. Robledo-Narváez, M.T. Ponce-Noyola, G. Calva-Calva, E. Ríos-Leal, J. Galíndez-Mayer, C. Estrada-Vázquez, A. Ortega-Clemente, N.F. Rinderknecht-Seijas, Biohydrogen, biomethane and bioelectricity as crucial components of biorefinery of

[54] W. Han, Y. Yan, J. Gu, Y. Shi, J. Tang, Y. Li, Techno-economic analysis of a novel bioprocess combining solid state fermentation and dark fermentation for $\mathrm{H} 2$ production from food waste, Int. J. Hydrogen Energy. 41 (2016) 22619-22625. doi:10.1016/j.ijhydene.2016.09.047.

616 [55] W. Han, J. Fang, Z. Liu, J. Tang, Techno-economic evaluation of a combined bioprocess for fermentative hydrogen production from food waste, Bioresour. Technol. 202 (2016) 107-112.

618 doi:10.1016/j.biortech.2015.11.072.

[56] E. Lalaurette, S. Thammannagowda, A. Mohagheghi, P.C. Maness, B.E. Logan, Hydrogen production from cellulose in a two-stage process combining fermentation and electrohydrogenesis, Int. J. Hydrogen Energy. 34 (2009) 6201-6210. doi:10.1016/j.ijhydene.2009.05.112.

622 [57] ECHEMI, Hydrochloric acid price market analysis, (2020). https://www.echemi.com/productsInformation/pid_Rock19088-hydrochloric-acid.html (accessed May 30, 
624 2020).

[58] Jiujiang Huirong New Materials Co. Ltd., Calcium hydroxide price, (2020). https://www.alibaba.com/productdetail/Bulk-Calcium-Hydroxide-

Price_60358348575.html?spm=a2700.7724857.normalList.8.5ed9172c3iyTux\&s=p (accessed May 30, 2020).

628 [59] Richin International Trade (Dalian) Co. Ltd., Ammonium chloride powder price, (2020). https://www.alibaba.com/product-detail/NH4Cl-Ammonium-Chloride-Powder-For-

630 Fertilizer_62560200713.html?spm=a2700.galleryofferlist.0.0.148619738dIDLo\&s=p.

[60] Tianjin Chengyuan Chemical Co. Ltd., Trisodium phosphate dodecahydrate price, (2020).

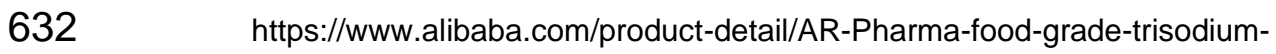
phosphate_62596584608.html?spm=a2700.galleryofferlist.0.0.2ba17c1bSLYWLG\&s=p\&fullFirstScreen=true 634 (accessed May 30, 2020).

[61] Tai'an Health Chemical Co. Ltd., Zinc chloride price, (2020). https://www.alibaba.com/product-detail/marketprice-of-zinc-chloride-95_60473427275.html?spm=a2700.details.deiletai6.9.2f5c181dOwJnz0\&bypass=true (accessed May 30, 2020).

638 [62] Liaoning Metals And Minerals Enterprise Co. Ltd., Magnesium chloride hexahydrate price, (2020). https://www.alibaba.com/product-detail/Hot-seller-best-price-46-

640 white_60780892964.html?bypass=true\&spm=a2700.galleryofferlist.0.0.1edb5dfbTCIWBk\&s=p (accessed May 30, 2020).

642 [63] Famouschem Technology (Shanghai) Co. Ltd., Manganese chloride tetrahydrate price, (2020). https://www.alibaba.com/product-detail/Factory-price-Manganese-chloride-tetrahydratewith_60793294844.html?spm=a2700.galleryofferlist.0.0.716229333KAfrf\&s=p\&fullFirstScreen=true.

[64] Shandong Shengpeng Sodium Silicate Co. Ltd., Ferric chloride hexahydrate price, (2020).

646 https://www.alibaba.com/product-detail/FeCl3-Ferric-Chloride-Hexahydrate-CAS10025_62123299735.html?bypass=true\&spm=a2700.galleryofferlist.0.0.7545346fpVos51\&s=p (accessed

648 May 30, 2020).

[65] Tai'an Health Chemical Co. Ltd., Copper chloride price, (2020). https://www.alibaba.com/productdetail/copper-chloride-cucl22h2o_60029943407.html?spm=a2700.galleryofferlist.0.0.e07875d4fs9DWj\&bypass=true (accessed May 30,

652 2020).

[66] Baofull Chemical Co. Limited (Liuzhou), Nickel chloride price, (2020). https://www.alibaba.com/productdetail/Nickel-Chloride-NiCl2-

656 2020).

\section{Abbreviations}

$\begin{array}{ll}660 & C S \\ & C_{C S} \\ 662 & C_{F V W} \\ & C_{R S} \\ 664 & C_{R S, i} \\ & C_{R S, f}\end{array}$

corn stover corn stover concentration in acid hydrolysis ( $\mathrm{g} \mathrm{g}^{-1}$ dry base) fruits-and-vegetables wastes concentration in acid hydrolysis ( $\mathrm{g} \mathrm{g}^{-1}$ dry base) reducing sugars concentration in acid hydrolysis $\left(\mathrm{g} \mathrm{L}^{-1}\right)$ reducing sugars initial concentration in dark fermentation $\left(g \mathrm{~L}^{-1}\right)$ reducing sugars final concentration in dark fermentation $\left(\mathrm{g} \mathrm{L}^{-1}\right)$ 


\begin{tabular}{|c|c|c|}
\hline 666 & $\begin{array}{l}\mathrm{C}_{\mathrm{H}_{3}+}^{+} \\
\mathrm{db}\end{array}$ & $\begin{array}{l}\text { theoretical hydronium concentration of the acid catalyst }\left(\mathrm{mol} \mathrm{H}_{3} \mathrm{O}^{+} \mathrm{L}^{-1}\right) \\
\text { dry basis }\end{array}$ \\
\hline \multirow[t]{2}{*}{668} & FVW & fruits-and-vegetables wastes \\
\hline & $H_{c s}$ & carbohydrates content in corn stover $\left(\mathrm{g} \mathrm{g}^{-1} \mathrm{db}\right)$ \\
\hline \multirow[t]{2}{*}{670} & $H_{F V W}$ & carbohydrates content in FVW ( $\left.\mathrm{g} \mathrm{g}^{-1} \mathrm{db}\right)$ \\
\hline & HMF & hydroxymethyl-furfural \\
\hline \multirow[t]{2}{*}{672} & $H(t)$ & cumulative hydrogen production at time ' $\mathrm{t}$ ' $\left(\mathrm{mL} \mathrm{H}_{2}\right)$ \\
\hline & $H_{\max }$ & maximum cumulative hydrogen production $\left(\mathrm{mL} \mathrm{H}_{2}\right)$ \\
\hline \multirow[t]{2}{*}{674} & $H P$ & hydrolysis potential $\left(\mathrm{g} \mathrm{mol}^{-1} \mathrm{H}_{3} \mathrm{O}^{+}\right)$ \\
\hline & ISR & inoculum substrate ratio \\
\hline \multirow[t]{2}{*}{676} & LH & liquid hydrolyzates \\
\hline & $m_{H}$ & co-substrates mass $(\mathrm{g})$ \\
\hline \multirow[t]{2}{*}{678} & $M W_{\text {glucose }}$ & glucose molar weight $\left(\mathrm{g} \mathrm{mol}^{-1}\right)$ \\
\hline & $R_{\max }$ & maximum hydrogen production rate $\left(\mathrm{mL} \mathrm{H}_{2} \mathrm{~h}^{-1}\right)$ \\
\hline \multirow[t]{2}{*}{680} & RS & reducing sugars \\
\hline & $t$ & time $(\mathrm{h})$ \\
\hline \multirow[t]{2}{*}{682} & TPC & total phenolic compounds \\
\hline & VFA & volatile fatty acids \\
\hline \multirow[t]{2}{*}{684} & VS & volatile solids \\
\hline & $V_{r}$ & hydrolysis volume (L) \\
\hline \multirow[t]{2}{*}{686} & $V_{R}$ & fermentation volume (L) \\
\hline & $Y_{\mathrm{H} 2}$ & hydrogen molar yield ( $\mathrm{mol} \mathrm{H}_{2}$ mol $^{-1}$ glucose) \\
\hline & $Y_{R S}$ & reducing sugars yield (\%) \\
\hline
\end{tabular}

690 Greek symbols

$\lambda$ lag time (h)

692 


\section{LIST OF FIGURES}

Fig. 1. Influence of fruits-and-vegetables wastes to corn stover ratios, FVW:CS, and acid catalysts, $696 \mathrm{HCl}$ or $\mathrm{H}_{2} \mathrm{SO}_{4}$, on $(\mathrm{A})$ reducing sugars production, $\mathrm{RS}$, and (B) hydrolysis potential, $H P$.

Fig. 2. Main effects on reducing sugars production yield, $Y_{R S}$, by $(A)$ fruits-and-vegetables wastes 698 to corn stover ratios, $\mathrm{FVW}: \mathrm{CS}$, and (B) acid catalysts, $\mathrm{HCl}$ or $\mathrm{H}_{2} \mathrm{SO}_{4}$.

Fig. 3. Monomeric sugars production at different fruits-and-vegetables wastes to corn stover 700 ratios, $\mathrm{FVW}: \mathrm{CS}$, by acid hydrolysis using $(\mathrm{A}) \mathrm{HCl}$, and $(\mathrm{B}) \mathrm{H}_{2} \mathrm{SO}_{4}$.

Fig. 4. Main effects by fruits-and-vegetables wastes to corn stover ratios, FVW:CS, and acid

702 catalysts, $\mathrm{HCl}$ or $\mathrm{H}_{2} \mathrm{SO}_{4}$ on the production of $\mathrm{HMF}(\mathrm{A}$ and $\mathrm{B})$, furfural $(\mathrm{C}$ and $\mathrm{D})$, and TPC (E and F).

704 Fig. 5. Cumulative hydrogen production by dark fermentation of overlimed HCl hydrolyzates from FVW:CS preparation at ISR equal to: $1.2(\mathrm{~A}), 1.0(\mathrm{~B})$, and $0.8(\mathrm{C})$. Reducing sugars initial 706 concentration, $C_{R S, i}$, were 10 (triangle), 13 (circle), and $16 \mathrm{~g} \mathrm{~L}^{-1}$ (square).

Fig. 6. Main effects by the reducing sugars initial concentration, $C_{R S, i}$, on the $(A)$ maximum 708 cumulative hydrogen production, $H_{\max }$, and $(\mathrm{B})$ the hydrogen molar yield, $Y_{\mathrm{H} 2}$.

710

712 


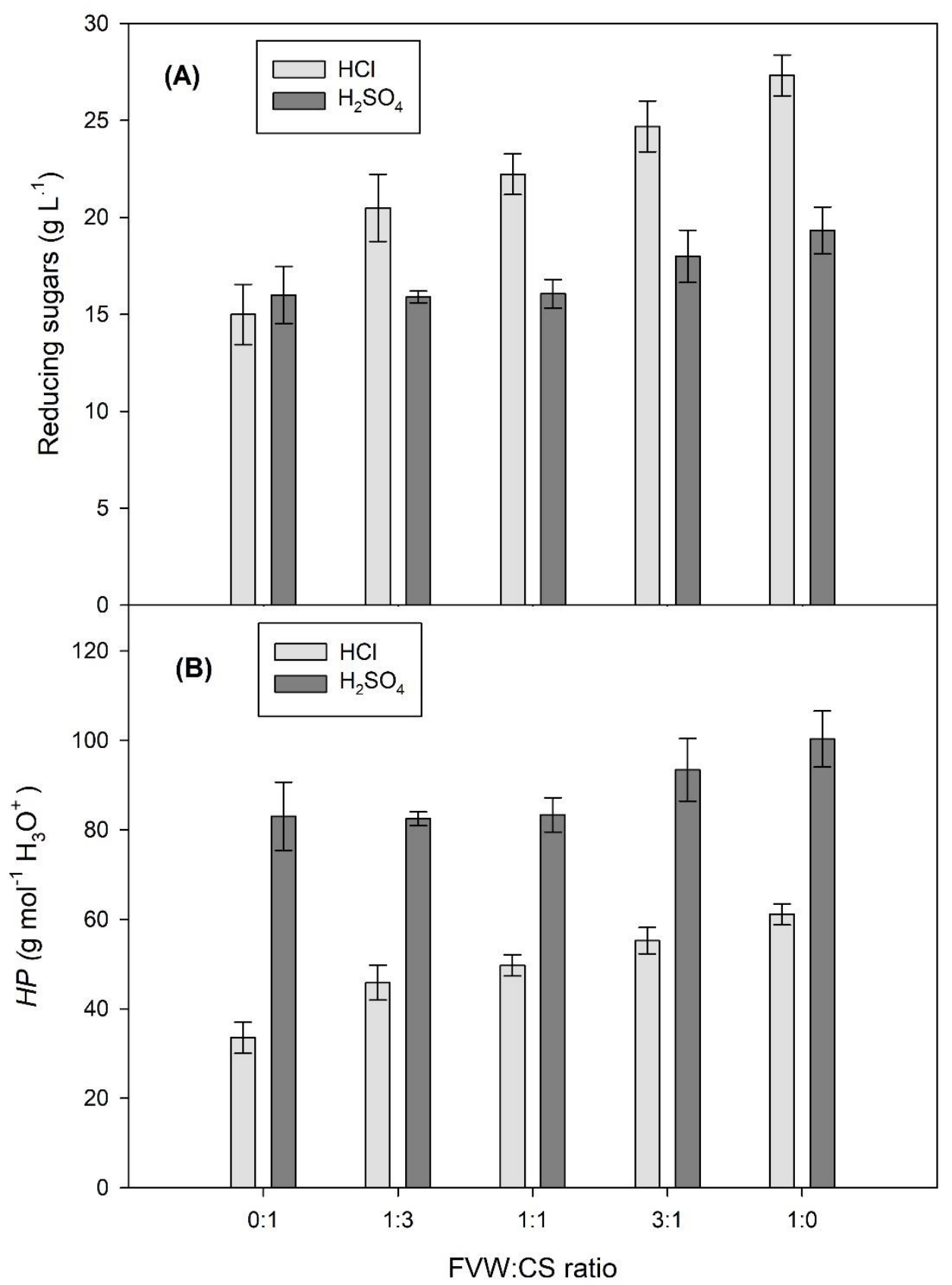

716 Fig. 1. Influence of fruits-and-vegetables wastes to corn stover ratios, FVW:CS, and acid 718 catalysts, $\mathrm{HCl}$ or $\mathrm{H}_{2} \mathrm{SO}_{4}$, on (A) reducing sugars production, $\mathrm{RS}$, and (B) hydrolysis potential, $H P$. 


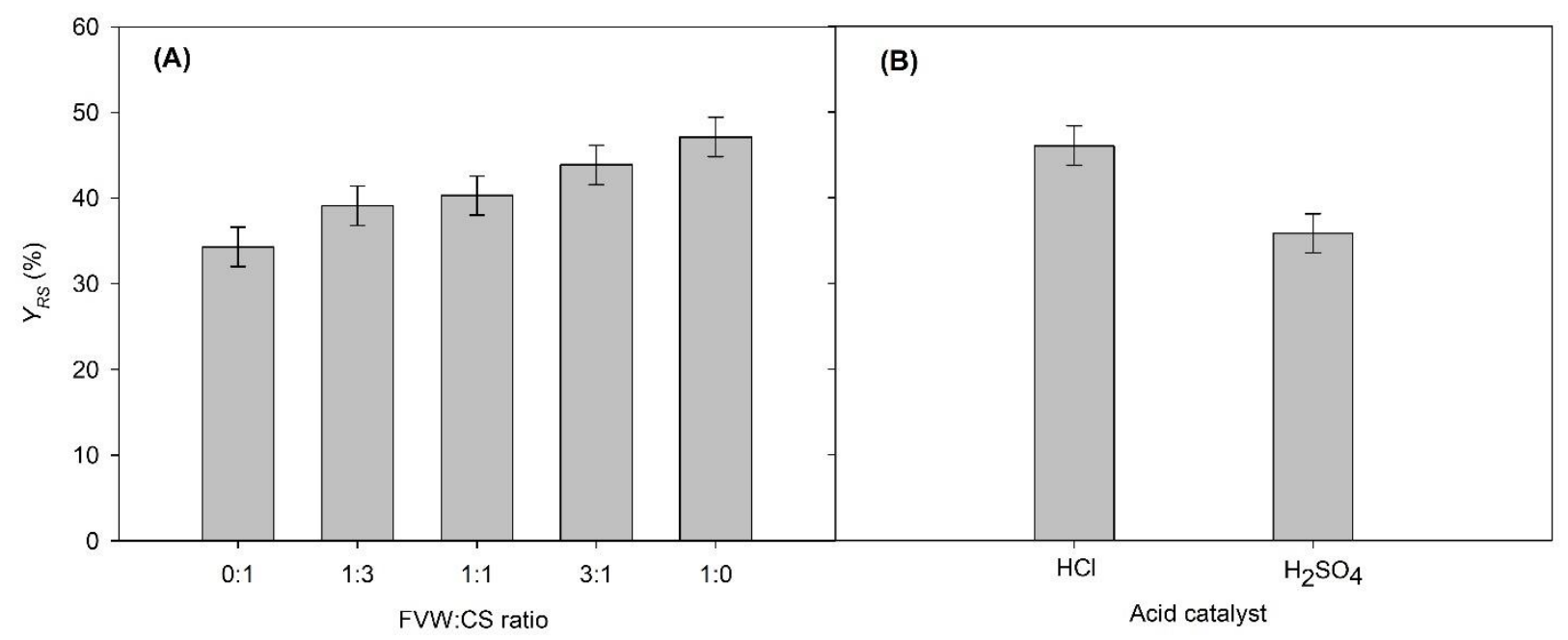

Fig. 2. Main effects on reducing sugars production yield, $Y_{R S}$, by (A) fruits-and-vegetables 722 wastes to corn stover ratios, FVW:CS, and (B) acid catalysts, $\mathrm{HCl}$ or $\mathrm{H}_{2} \mathrm{SO}_{4}$. 


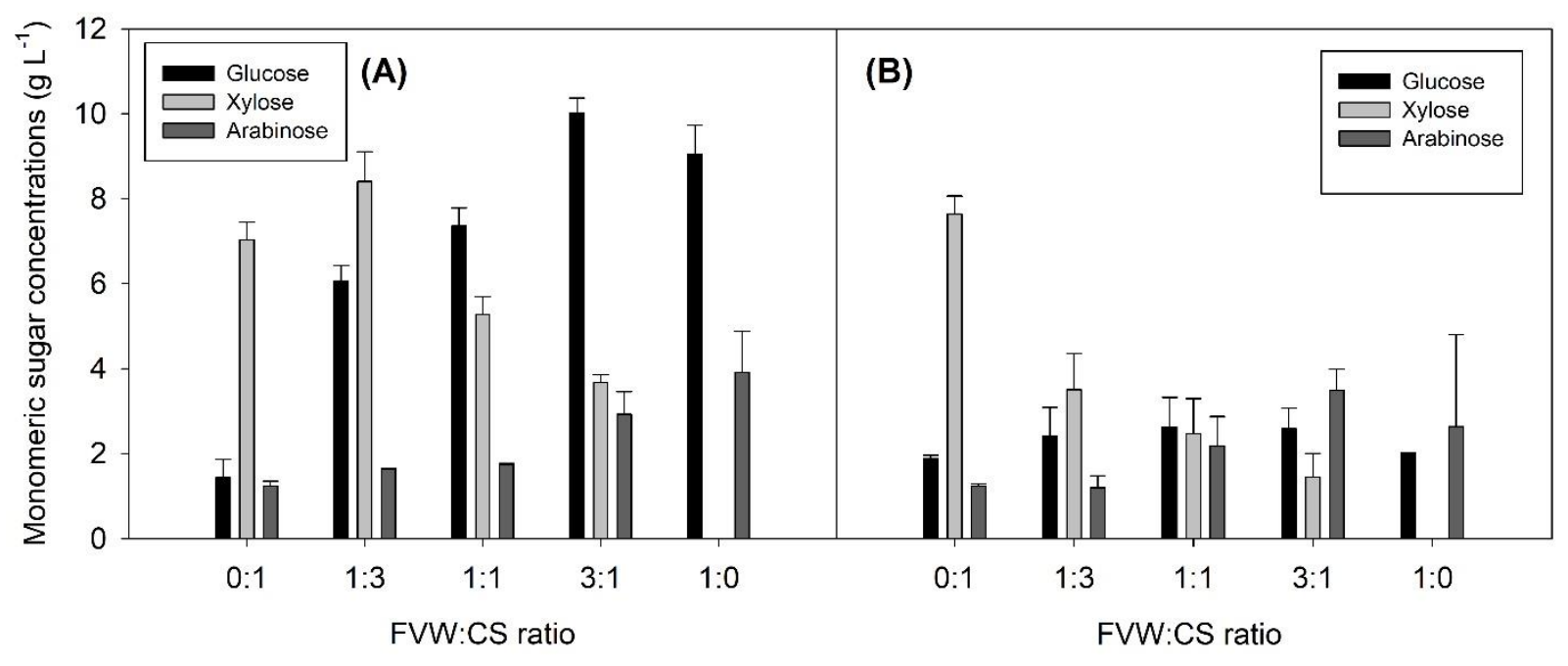

Fig. 3. Monomeric sugars production at different fruits-and-vegetables wastes to corn 728 stover ratios, FVW:CS, by acid hydrolysis using $(A) \mathrm{HCl}$, and $(B) \mathrm{H}_{2} \mathrm{SO}_{4}$. 


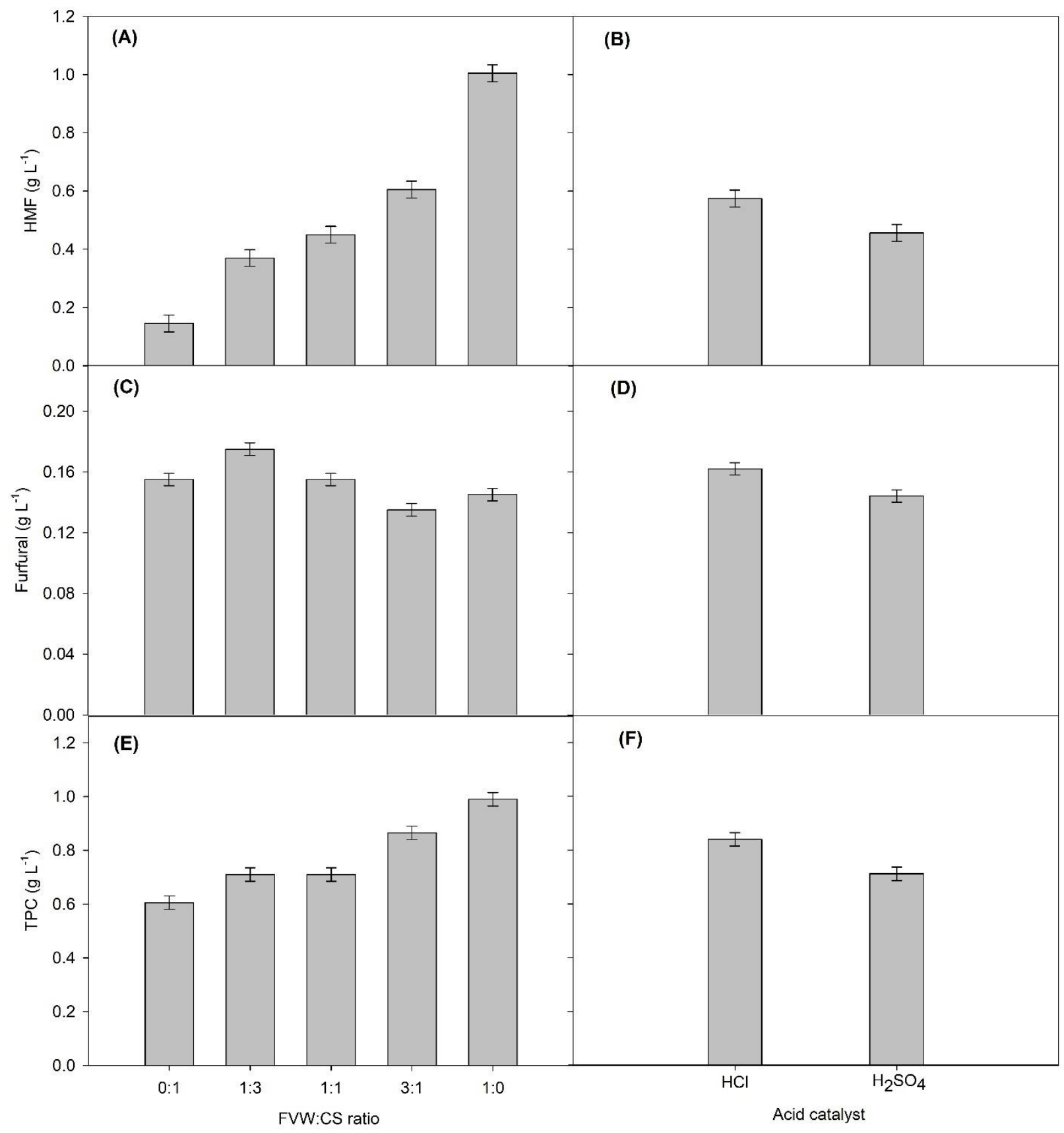

734 Fig. 4. Main effects by fruits-and-vegetables wastes to corn stover ratios, FVW:CS, and 736 acid catalysts, $\mathrm{HCl}$ or $\mathrm{H}_{2} \mathrm{SO}_{4}$ on the production of $\mathrm{HMF}$ ( $A$ and $B$ ), furfural (C and $D$ ), and TPC (E and F). 


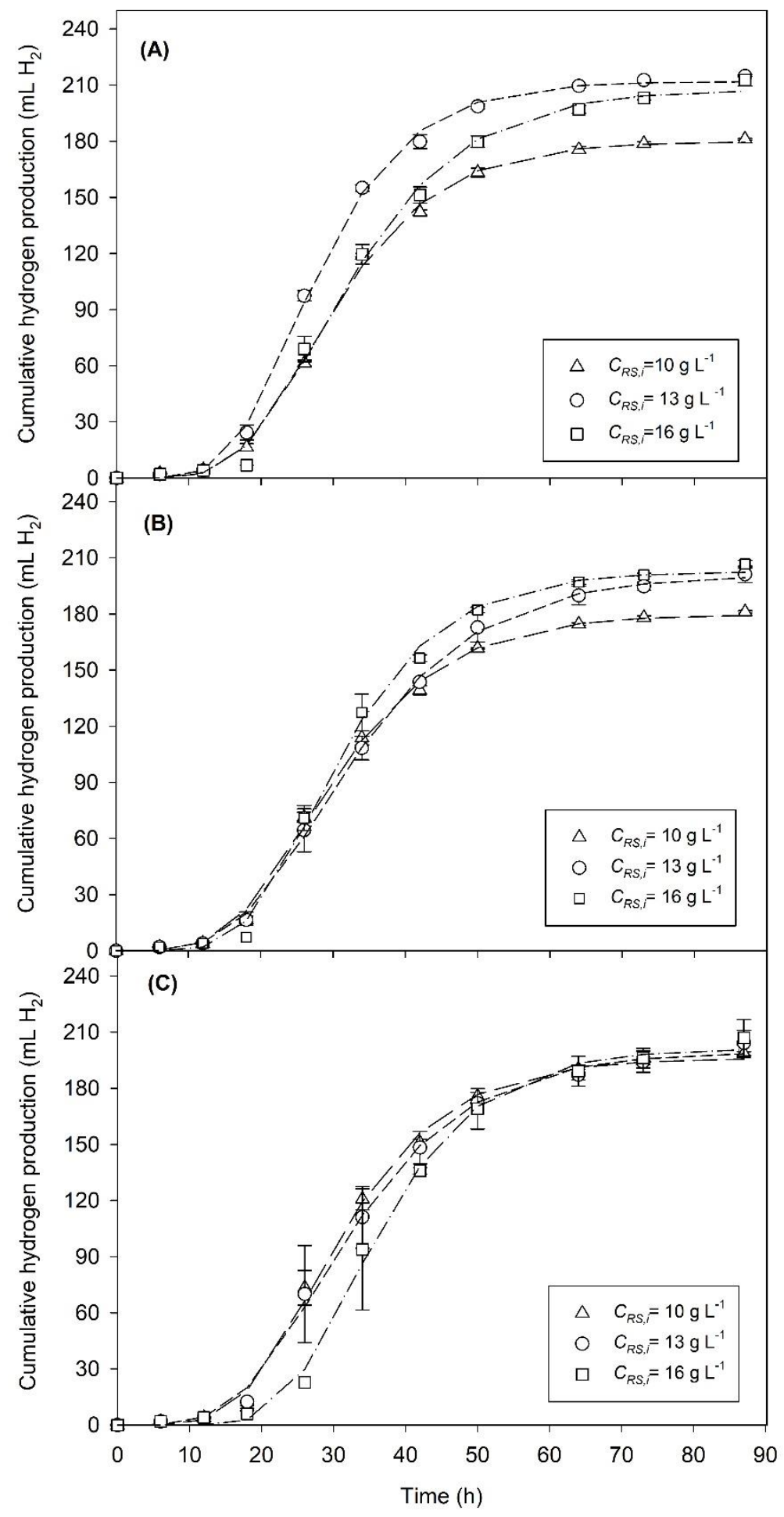

Fig. 5. Cumulative hydrogen production by dark fermentation of overlimed $\mathrm{HCl}$ 740 hydrolyzates from FVW:CS preparation at ISR equal to: 1.2 (A), 1.0 (B), and 0.8 (C). 742 Reducing sugars initial concentration $\left(C_{R S, i}\right)$ were 10 (triangle), 13 (circle), and $16 \mathrm{~g} \mathrm{~L}^{-1}$ (square) 


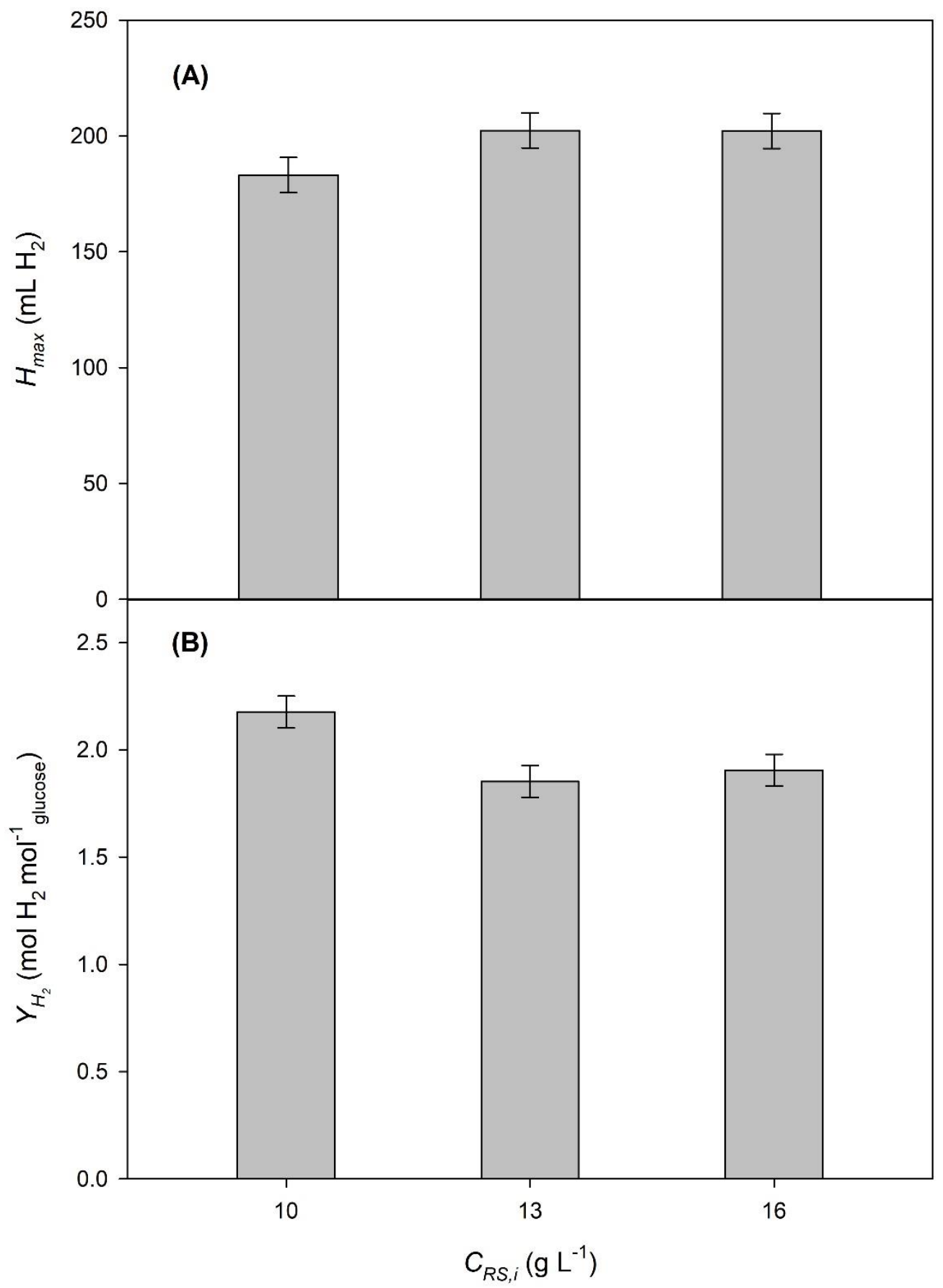

744 Fig. 6 . Main effects by the reducing sugars initial concentration, $C_{R S, i}$, on the (A) maximum cumulative hydrogen production, $\boldsymbol{H}_{\max }$, and (B) the hydrogen molar yield, $\boldsymbol{Y}_{\mathrm{H} 2}$. 


\section{LIST OF TABLES}

748 Table 1. Secondary products concentration from acid hydrolysis of fruits-and-vegetables wastes to corn stover ratios, FVW:CS.

750 Table 2. Parameters of the modified Gompertz equation of the factorial design $3^{2}$ from the $\mathrm{HCl}$

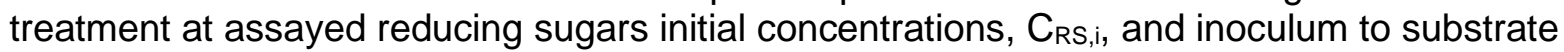

752 ratios, ISR.

Table 3. Secondary metabolites and response variables of hydrogen production of $\mathrm{HCl}$

754 hydrolyzates, at assayed reducing sugars initial concentrations, $\mathrm{C}_{\mathrm{RS}, \mathrm{i}}$, and inoculum to substrate ratios, ISR.

756 Table 4. Hydrogen production by dark fermentation of organic wastes.

Table 5. Economic prospection of hydrogen production from FVW:CS (3:1 ratio) at lab scale. 


\begin{tabular}{|c|c|c|c|c|c|c|c|c|}
\hline $\begin{array}{c}\text { FVW:CS ratio and } \\
\text { acid catalyst }\end{array}$ & $\begin{array}{c}\text { HMF } \\
\left(\mathrm{g} \mathrm{L}^{-1}\right)\end{array}$ & $\begin{array}{c}\text { Furfural } \\
\left(\mathrm{g} \mathrm{L}^{-1}\right)\end{array}$ & $\begin{array}{l}\text { TPC } \\
\left(g^{-1}\right)\end{array}$ & $\begin{array}{c}\text { Formic acid } \\
\left(\mathrm{g} \mathrm{L}^{-1}\right)\end{array}$ & $\begin{array}{c}\text { Acetic acid } \\
\left(\mathrm{g} \mathrm{L}^{-1}\right)\end{array}$ & $\begin{array}{c}\text { Propionic acid } \\
\left(\mathrm{g} \mathrm{L}^{-1}\right)\end{array}$ & $\begin{array}{c}\text { Succinic acid } \\
\left(\mathrm{g} \mathrm{L}^{-1}\right)\end{array}$ & $\begin{array}{c}\text { Lactic acid } \\
\left(\mathrm{g} \mathrm{L}^{-1}\right)\end{array}$ \\
\hline $0: 1 \mathrm{HCl}$ & $0.14 \pm 0.00$ & $0.14 \pm 0.00$ & $0.63 \pm 0.01$ & $6.13 \pm 0.07$ & $0.74 \pm 0.16$ & $0.86 \pm 0.00$ & $0.18 \pm 0.00$ & $0.18 \pm 0.03$ \\
\hline $0: 1 \mathrm{H}_{2} \mathrm{SO}_{4}$ & $0.15 \pm 0.00$ & $0.17 \pm 0.00$ & $0.58 \pm 0.02$ & $5.80 \pm 0.49$ & $0.77 \pm 0.08$ & $0.75 \pm 0.43$ & $0.17 \pm 0.00$ & $0.17 \pm 0.00$ \\
\hline $1: 3 \mathrm{HCl}$ & $0.47 \pm 0.02$ & $0.21 \pm 0.01$ & $0.79 \pm 0.02$ & $5.37 \pm 0.30$ & $0.84 \pm 0.24$ & $1.09 \pm 0.45$ & $0.17 \pm 0.01$ & $0.83 \pm 0.24$ \\
\hline $1: 3 \mathrm{H}_{2} \mathrm{SO}_{4}$ & $0.27 \pm 0.04$ & $0.14 \pm 0.01$ & $0.63 \pm 0.01$ & $3.10 \pm 0.86$ & $0.45 \pm 0.09$ & $0.76 \pm 0.21$ & $0.16 \pm 0.01$ & $0.54 \pm 0.12$ \\
\hline $1: 1 \mathrm{HCl}$ & $0.45 \pm 0.04$ & $0.17 \pm 0.00$ & $0.77 \pm 0.02$ & $3.42 \pm 0.87$ & $0.51 \pm 0.09$ & $1.05 \pm 0.34$ & $0.16 \pm 0.01$ & $0.57 \pm 0.49$ \\
\hline $1: 1 \mathrm{H}_{2} \mathrm{SO}_{4}$ & $0.45 \pm 0.04$ & $0.14 \pm 0.01$ & $0.65 \pm 0.02$ & $4.29 \pm 0.44$ & $0.46 \pm 0.07$ & $1.64 \pm 0.15$ & $0.17 \pm 0.00$ & $1.15 \pm 0.09$ \\
\hline $3: 1 \mathrm{HCl}$ & $0.65 \pm 0.01$ & $0.14 \pm 0.00$ & $0.90 \pm 0.04$ & $4.02 \pm 0.15$ & $0.53 \pm 0.01$ & $1.80 \pm 0.06$ & $0.16 \pm 0.00$ & $1.39 \pm 0.05$ \\
\hline $3: 1 \mathrm{H}_{2} \mathrm{SO}_{4}$ & $0.56 \pm 0.01$ & $0.13 \pm 0.00$ & $0.83 \pm 0.12$ & $3.83 \pm 0.38$ & $0.48 \pm 0.03$ & $2.10 \pm 0.23$ & $0.17 \pm 0.00$ & $1.43 \pm 0.17$ \\
\hline $1: 0 \mathrm{HCl}$ & $1.16 \pm 0.01$ & $0.15 \pm 0.01$ & $1.11 \pm 0.03$ & $6.30 \pm 0.72$ & $0.79 \pm 0.12$ & $3.78 \pm 0.37$ & $0.21 \pm 0.01$ & $2.99 \pm 0.30$ \\
\hline $1: 0 \mathrm{H}_{2} \mathrm{SO}_{4}$ & $0.85 \pm 0.14$ & $0.14 \pm 0.01$ & $0.87 \pm 0.01$ & $6.59 \pm 0.58$ & $0.77 \pm 0.19$ & $4.27 \pm 0.28$ & $0.21 \pm 0.01$ & $3.06 \pm 0.53$ \\
\hline
\end{tabular}

762 Notes: FVW:CS of fruits-and-vegetables wastes to corn stover ratios; HMF, Hydroxymethyl-furfural; TPC, Total phenolic compounds. 
Table 2. Parameters of the modified Gompertz equation of the factorial design $3^{2}$ from the $774 \mathrm{HCl}$ treatment at assayed reducing sugars initial concentrations, $\mathrm{C}_{\mathrm{RS}, \mathrm{i}}$, and inoculum to substrate ratios, ISR.

\begin{tabular}{|c|c|c|c|c|c|c|c|}
\hline \multirow[t]{2}{*}{ Assay } & \multicolumn{2}{|c|}{ Real values } & \multicolumn{2}{|c|}{ Coded values } & \multirow{2}{*}{$\begin{array}{c}H_{\max } \\
\left(\mathrm{mL} \mathrm{H}_{2}\right)\end{array}$} & \multirow{2}{*}{$\begin{array}{c}R_{\max } \\
\left(\mathrm{mL} \mathrm{H_{2 }} \mathbf{h}^{-1}\right)\end{array}$} & \multirow{2}{*}{$\begin{array}{c}\lambda \\
\text { (h) }\end{array}$} \\
\hline & $C_{R S, i}\left(\mathrm{~g} \mathrm{~L}^{-1}\right)$ & ISR & $C_{R S, i}$ & ISR & & & \\
\hline 1 & 10 & 1.2 & -1 & 1 & 180 & 6.70 & 16.5 \\
\hline 2 & 13 & 1.2 & 0 & 1 & 212 & 8.83 & 15.4 \\
\hline 3 & 16 & 1.2 & 1 & 1 & 208 & 6.92 & 17.0 \\
\hline 4 & 10 & 1.0 & -1 & 0 & 180 & 6.19 & 15.2 \\
\hline 5 & 13 & 1.0 & 0 & 0 & 201 & 6.13 & 16.1 \\
\hline 6 & 16 & 1.0 & 1 & 0 & 203 & 7.61 & 17.3 \\
\hline 7 & 10 & 0.8 & -1 & -1 & 196 & 7.03 & 16.6 \\
\hline 8 & 13 & 0.8 & 0 & -1 & 200 & 6.34 & 16.1 \\
\hline 9 & 16 & 0.8 & 1 & -1 & 201 & 7.52 & 22.5 \\
\hline
\end{tabular}

776 Note: For all experiments, $\mathrm{R}^{2}$ was greater than 0.99; $H_{\max }$, maximum cumulative hydrogen production; $R_{\max }$, 778 maximum hydrogen production rate; $\lambda$, lag time $(h)$.

780

782 
Table 3. Secondary metabolites and response variables of hydrogen production of $\mathrm{HCl}$ hydrolyzates, at assayed reducing sugars initial concentrations, $\mathrm{C}_{\mathrm{RS}, \mathrm{i}}$, and inoculum to substrate ratios, ISR.

\begin{tabular}{|c|c|c|c|c|c|c|c|c|c|}
\hline$C_{R S, r}$ ISR & $\begin{array}{c}\text { Final } \\
\text { pH }\end{array}$ & $\begin{array}{l}\text { Ethanol } \\
\left(\mathrm{g} \mathrm{L}^{-1}\right)\end{array}$ & $\begin{array}{l}\text { Acetic } \\
\text { acid } \\
\left(\mathrm{g} \mathrm{L}^{-1}\right)\end{array}$ & $\begin{array}{l}\text { Propionic } \\
\text { acid } \\
\left(\mathrm{g} \mathrm{L}^{-1}\right)\end{array}$ & $\begin{array}{l}\text { Butyric } \\
\text { acid } \\
\left(\mathrm{g} \mathrm{L}^{-1}\right)\end{array}$ & $\begin{array}{l}\text { TVFA } \\
\left(g^{-1}\right)\end{array}$ & $\begin{array}{c}\text { Volumetric } \\
\text { productivity } \\
\left(\mathrm{mL} \mathrm{H}_{2} \mathrm{~L}^{-1} \text { reactor) }\right.\end{array}$ & $\begin{array}{c}\text { RS } \\
\text { consumption } \\
(\%)\end{array}$ & $\begin{array}{c}Y_{\mathrm{H} 2} \\
\left(\mathrm{~mol} \mathrm{H} \mathrm{mol}^{-1} \text { glucose }\right.\end{array}$ \\
\hline $10-1.2$ & 6.02 & 0.06 & 2.30 & 0.29 & 4.34 & 6.93 & 2474 & 95.36 & 2.14 \\
\hline $16-1.2$ & 5.25 & 0.05 & 1.30 & 0.13 & 1.61 & 3.04 & 2905 & 80.38 & 1.81 \\
\hline $10-1.0$ & 5.96 & 0.04 & 1.92 & 0.29 & 3.78 & 5.99 & 2473 & 95.27 & 2.08 \\
\hline $13-1.0$ & 5.90 & 0.05 & 2.01 & 0.27 & 5.09 & 7.37 & 2747 & 95.94 & 1.82 \\
\hline $10-0.8$ & 5.71 & 0.13 & 2.10 & 0.36 & 3.61 & 6.07 & 2712 & 95.33 & 2.31 \\
\hline $13-0.8$ & 5.67 & 0.06 & 2.09 & 0.30 & 5.37 & 7.76 & 2789 & 94.92 & 1.82 \\
\hline $16-0.8$ & 5.17 & 0.06 & 1.88 & 0.13 & 2.73 & 4.74 & 2827 & 69.96 & 2.05 \\
\hline
\end{tabular}

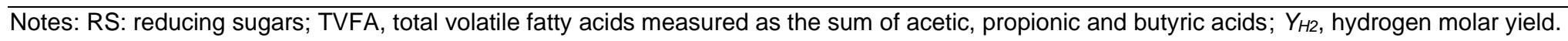


Table 4. Hydrogen production by dark fermentation of organic wastes.

\begin{tabular}{|c|c|c|c|c|c|c|}
\hline Inoculum & $\begin{array}{c}\text { Substrate } \\
\text { (initial } \\
\text { concentration) }\end{array}$ & $\begin{array}{l}\text { Operational } \\
\text { conditions }\end{array}$ & ISR & $\begin{array}{c}\text { Hydrogen } \\
\text { production and } \\
\text { Gompertz kinetic } \\
\text { parameters }\end{array}$ & $\begin{array}{c}\text { Hydrogen molar } \\
\text { yield } \\
\left(Y_{H 2}\right) \text { and } \\
\text { volumetric } \\
\text { productivity }\left(\mathrm{P}_{\mathrm{v}}\right)\end{array}$ & Ref \\
\hline $\begin{array}{l}\text { Thermoanaerobact } \\
\text { erium } \\
\text { thermosaccharolyt } \\
\text { icum W16 }\end{array}$ & $\begin{array}{l}\text { Corn stover acid } \\
\text { hydrolyzates } \\
\left(11.84 \mathrm{~g} \mathrm{~L}^{-1}\right)\end{array}$ & $\begin{aligned} \mathrm{V}_{\mathrm{o}} & =50 \mathrm{~mL} \\
\mathrm{~T} & =60^{\circ} \mathrm{C} \\
\mathrm{t} & =30 \mathrm{~h}\end{aligned}$ & 0.0123 & $\begin{array}{c}H_{\max }=165 \mathrm{~mL} \\
R_{\max }=5.51 \mathrm{~mL} \mathrm{~h}^{-1} \\
\lambda=4 \mathrm{~h}\end{array}$ & $\begin{array}{l}2.24 \mathrm{~mol} \mathrm{H}_{2} \mathrm{~mol} \\
\text { glucose } \\
\mathrm{P}_{\mathrm{v}}=3305 \mathrm{~mL} \mathrm{~L}^{-1}\end{array}$ & {$[44]$} \\
\hline $\begin{array}{l}\text { Clostridium } \\
\text { butyricum }\end{array}$ & $\begin{array}{l}\text { Sugarcane } \\
\text { bagasse } \\
\text { hydrolyzates } \\
\left(20 \mathrm{~g} \mathrm{~L}^{-1}\right)\end{array}$ & $\begin{aligned} \mathrm{V}_{\mathrm{o}} & =70 \mathrm{~mL} \\
\mathrm{~T} & =37^{\circ} \mathrm{C} \\
\mathrm{t} & =60 \mathrm{~h}\end{aligned}$ & 0.001 & $\begin{array}{c}H_{\max }=180 \mathrm{~mL} \\
R_{\max }=3 \mathrm{~mL} \mathrm{~h}^{-1} \\
\lambda=5 \mathrm{~h}\end{array}$ & $\begin{array}{c}1.73 \mathrm{~mol} \mathrm{H}_{2} \mathrm{~mol} \\
\text { glucose }^{-1} \\
\mathrm{P}_{\mathrm{v}}=\underset{1}{2571.43 \mathrm{~mL} \mathrm{~L}^{-}}\end{array}$ & [49] \\
\hline Anaerobic sludge & $\begin{array}{l}\text { Food waste and } \\
\text { sewage sludge } \\
\left(15.5 \mathrm{~g} \mathrm{~L}^{-1}\right)\end{array}$ & $\begin{array}{c}\mathrm{V}_{\mathrm{o}}=415 \mathrm{~mL} \\
\mathrm{~T}=35^{\circ} \mathrm{C} \\
\mathrm{t}=216 \mathrm{~h}\end{array}$ & 0.041 & $\begin{array}{c}H_{\max }=359 \mathrm{~mL} \\
R_{\max }=14.93 \mathrm{~mL} \mathrm{~h}^{-1} \\
\lambda=6.48 \mathrm{~h}\end{array}$ & $\begin{array}{c}0.98 \mathrm{~mol} \mathrm{H}_{2} \mathrm{~mol} \\
\text { glucose }^{-1} \\
\mathrm{P}_{\mathrm{v}}=796.39 \mathrm{~mL} \mathrm{~L}^{-1}\end{array}$ & [13] \\
\hline Anaerobic sludge & $\begin{array}{l}\text { Corn stover } \\
\text { steam-explosion } \\
\left(10.98 \mathrm{~g} \mathrm{~L}^{-1}\right)\end{array}$ & $\begin{array}{c}\mathrm{V}_{\mathrm{o}}=1250 \mathrm{~mL} \\
\mathrm{~T}=35^{\circ} \mathrm{C} \\
\mathrm{t}=78 \mathrm{~h}\end{array}$ & 0.4 & $\begin{array}{c}H_{\max }=4138 \mathrm{~mL} \\
R_{\max }=206 \mathrm{~mL} \mathrm{~h}^{-1} \\
\lambda=38 \mathrm{~h}\end{array}$ & $\begin{array}{c}2.42 \mathrm{~mol} \mathrm{H}_{2} \mathrm{~mol} \\
\text { glucose } \\
\mathrm{P}_{\mathrm{v}}=3310 \mathrm{~mL} \mathrm{~L}^{-1}\end{array}$ & {$[8]$} \\
\hline Activated sludge & $\begin{array}{l}\text { Corn stover acid } \\
\text { hydrolyzates } \\
\left(5 \mathrm{~g} \mathrm{~L}^{-1}\right)\end{array}$ & $\begin{aligned} \mathrm{V}_{\mathrm{o}} & =50 \mathrm{~mL} \\
\mathrm{~T} & =37^{\circ} \mathrm{C} \\
\mathrm{t} & =60 \mathrm{~h}\end{aligned}$ & 0.032 & $\begin{array}{c}H_{\max }=14 \mathrm{~mL} \\
R_{\max }=0.22 \mathrm{~mL} \mathrm{~h}^{-1} \\
\lambda=15.3 \mathrm{~h}\end{array}$ & $\begin{array}{c}0.44 \mathrm{~mol} \mathrm{H}_{2} \mathrm{~mol} \\
\text { glucose } \\
\mathrm{P}_{\mathrm{v}}=275 \mathrm{~mL} \mathrm{~L}^{-1}\end{array}$ & {$[50]$} \\
\hline $\begin{array}{l}\text { Granular } \\
\text { anaerobic sludge }\end{array}$ & $\begin{array}{l}\text { Corn stover acid } \\
\text { hydrolyzates } \\
\left(5 \mathrm{~g} \mathrm{~L}^{-1}\right)\end{array}$ & $\begin{aligned} \mathrm{V}_{\mathrm{o}} & =50 \mathrm{~mL} \\
\mathrm{~T} & =37^{\circ} \mathrm{C} \\
\mathrm{t} & =60 \mathrm{~h}\end{aligned}$ & 0.192 & $\begin{array}{c}H_{\max }=11 \mathrm{~mL} \\
R_{\max }=0.19 \mathrm{~mL} \mathrm{~h}^{-1} \\
\lambda=15.4 \mathrm{~h}\end{array}$ & $\begin{array}{c}0.35 \mathrm{~mol} \mathrm{H}_{2} \mathrm{~mol} \\
\text { glucose } \\
\mathrm{P}_{\mathrm{v}}= \\
223.6 \mathrm{~mL} \mathrm{~L}^{-1}\end{array}$ & {$[56]$} \\
\hline Anaerobic sludge & $\begin{array}{l}\text { Organic fraction } \\
\text { of municipal } \\
\text { solid waste } \\
\left(150 \mathrm{~g} \mathrm{kgr}^{-1}\right)\end{array}$ & $\begin{array}{l}\mathrm{V}_{\mathrm{o}}=500 \mathrm{~g} \\
\mathrm{~T}=55^{\circ} \mathrm{C} \\
\mathrm{t}=470 \mathrm{~h}\end{array}$ & 0.068 & $\begin{array}{c}H_{\max }{ }^{a}=331 \mathrm{~mL} \\
R_{\max }=0.70 \mathrm{~mL} \mathrm{~h}^{-1} \\
\lambda^{\mathrm{a}}=0 \mathrm{~h}\end{array}$ & $\begin{array}{l}0.29 \mathrm{~mol} \mathrm{H}_{2} \mathrm{~mol} \\
\text { glucose } \\
\mathrm{P}_{\mathrm{v}}=662 \mathrm{~mL} \mathrm{~g}^{-1}\end{array}$ & [2] \\
\hline Anaerobic sludge & $\begin{array}{l}\text { FVW:CS acid } \\
\text { hydrolyzates at } \\
3: 1 \text { ratio } \\
\left(13 \mathrm{~g} \mathrm{~L}^{-1}\right)\end{array}$ & $\begin{aligned} \mathrm{V}_{\mathrm{o}} & =70 \mathrm{~mL} \\
\mathrm{~T} & =35^{\circ} \mathrm{C} \\
\mathrm{t} & =87 \mathrm{~h}\end{aligned}$ & 1.2 & $\begin{array}{c}H_{\max }{ }^{\mathrm{a}}=212 \mathrm{~mL} \\
R_{\max }{ }^{\mathrm{a}}=8.83 \mathrm{~mL} \mathrm{~h}^{-1} \\
\lambda^{\mathrm{a}}=15.35 \mathrm{~h}\end{array}$ & $\begin{array}{c}1.91 \mathrm{~mol} \mathrm{H}_{2} \mathrm{~mol} \\
\text { glucose } \\
\mathrm{P}_{\mathrm{v}}=2933 \mathrm{~mL} \mathrm{~L}^{-1}\end{array}$ & $\begin{array}{l}\text { This } \\
\text { work }\end{array}$ \\
\hline
\end{tabular}

Notes: ${ }^{a}$ Experimental data; CS, corn stover; FVW, fruits and vegetables wastes; $H_{\max }$, maximum cumulative hydrogen production; ISR, inoculum to substrate ratio; $\mathrm{P}_{\mathrm{v}}$, volumetric productivity (hydrogen production/oper); $R_{\max }$, maximum hydrogen production rate; $\mathrm{T}$, temperature $\left({ }^{\circ} \mathrm{C}\right) ; \mathrm{t}$, time $(\mathrm{h}) ; \mathrm{V}_{\mathrm{O}}$, operational volume $(\mathrm{mL}) ; Y_{\mathrm{H} 2}$, hydrogen molar yield; $\lambda$, 796 lag time (h). 
800

Table 5. Economic prospection of hydrogen production from FVW:CS (3:1 ratio) at lab scale.

\begin{tabular}{|c|c|c|c|c|c|c|}
\hline Stage & Component & $\begin{array}{l}\text { Price } \\
\text { (USD/kg) }\end{array}$ & Quantity & Unit & Price (USD) & Ref \\
\hline \multirow[t]{2}{*}{ Raw materials } & CS & 0.088 & 0.035 & $\mathrm{~kg}$ & -0.003 & [31] \\
\hline & FVW & 0.013 & 0.965 & $\mathrm{~kg}$ & -0.013 & {$[32,33]$} \\
\hline $\begin{array}{l}\text { Co-substrates size } \\
\text { reduction }\end{array}$ & Electricity & 0.014 & 0.089 & MJ & -0.001 & [34] \\
\hline \multirow[t]{3}{*}{ Acid hydrolysis } & $\mathrm{HCl}(30 \%)$ & 0.029 & 0.039 & $\mathrm{~kg}$ & -0.001 & [57] \\
\hline & Water & 0.0006 & 1.079 & $\mathrm{~kg}$ & -0.001 & [35] \\
\hline & Electricity & 0.014 & 0.322 & MJ & -0.004 & [34] \\
\hline $\begin{array}{l}\text { Mechanical } \\
\text { separation }\end{array}$ & Electricity & 0.014 & 0.012 & MJ & -0.002 & [34] \\
\hline \multirow{2}{*}{$\begin{array}{l}\text { Overliming } \\
\text { pretreatment }\end{array}$} & $\mathrm{Ca}(\mathrm{OH})_{2}$ & 0.12 & 0.013 & $\mathrm{~kg}$ & -0.002 & [58] \\
\hline & Electricity & 0.014 & 0.009 & MJ & -0.0001 & [34] \\
\hline \multirow[t]{11}{*}{ Dark fermentation } & $\mathrm{NH}_{4} \mathrm{Cl}$ & 0.11 & 0.003 & $\mathrm{~kg}$ & -0.0004 & [59] \\
\hline & Buffer media & 0.3 & 0.008 & $\mathrm{~kg}$ & -0.0023 & [60] \\
\hline & Water & 0.0006 & 0.016 & $\mathrm{~kg}$ & -0.00001 & [35] \\
\hline & $\mathrm{ZnCl}_{2}$ & 0.9 & 0.0002 & $\mathrm{~kg}$ & -0.0002 & [61] \\
\hline & $\mathrm{MgCl}_{2} \cdot 6 \mathrm{H}_{2} \mathrm{O}$ & 0.1 & 0.0003 & $\mathrm{~kg}$ & -0.00003 & [62] \\
\hline & $\mathrm{MnCl}_{2} \cdot 4 \mathrm{H}_{2} \mathrm{O}$ & 2 & 0.00004 & $\mathrm{~kg}$ & -0.00007 & [63] \\
\hline & $\mathrm{FeCl}_{3} \cdot 6 \mathrm{H}_{2} \mathrm{O}$ & 2 & 0.00009 & $\mathrm{~kg}$ & -0.00017 & [64] \\
\hline & $\mathrm{CuCl}_{2} \cdot 2 \mathrm{H}_{2} \mathrm{O}$ & 2.5 & 0.00001 & $\mathrm{~kg}$ & -0.00003 & [65] \\
\hline & $\mathrm{NiCl}_{2} \cdot 6 \mathrm{H}_{2} \mathrm{O}$ & 3 & 0.0003 & $\mathrm{~kg}$ & -0.001 & [66] \\
\hline & $\mathrm{H}_{2}$ & 0.0027 & 13.353 & $\mathrm{~L}$ & 0.036 & [39] \\
\hline & $\mathrm{CO}_{2}$ & 0.0003 & 6.663 & $\mathrm{~L}$ & 0.002 & [39] \\
\hline Total system cost & & & & & -0.029 & \\
\hline Total revenue & & & & & 0.038 & \\
\hline Total Net & & & & & 0.009 & \\
\hline
\end{tabular}

802

804 